Florida International University FIU Digital Commons

$11-2-2011$

\title{
The Civic Achievement Gap: A Study on the Civic Knowledge, Skills, and Attitudes of Hispanic Students in Miami-Dade County Public Schools
}

Sergio Nieves

Florida International University, sniev001@fiu.edu

DOI: $10.25148 /$ etd.FI11120512

Follow this and additional works at: https://digitalcommons.fiu.edu/etd

\section{Recommended Citation}

Nieves, Sergio, "The Civic Achievement Gap: A Study on the Civic Knowledge, Skills, and Attitudes of Hispanic Students in MiamiDade County Public Schools" (2011). FIU Electronic Theses and Dissertations. 493.

https://digitalcommons.fiu.edu/etd/493 


\section{FLORIDA INTERNATIONAL UNIVERSITY}

Miami, Florida

\section{THE CIVIC ACHIEVEMENT GAP: A STUDY ON THE CIVIC KNOWLEDGE, SKILLS, AND ATTITUDES OF HISPANIC STUDENTS IN MIAMI-DADE COUNTY PUBLIC SCHOOLS}

A dissertation submitted in partial fulfillment of the requirements for the degree of DOCTOR OF EDUCATION

in CURRICULUM AND INSTRUCTION

by

Sergio Nieves

2011 
To: Dean Delia C. Garcia

College of Education

This dissertation, written by Sergio Nieves, and entitled The Civic Achievement Gap: A Study on the Civic Knowledge, Skills, and Attitudes of Hispanic Students in Miami-Dade County Public Schools having been approved in respect to style and intellectual content, is referred to you for judgment.

We have read this dissertation and recommend that it be approved.

Hilary Landorf

Leonard Bliss

Aixa Perez-Prado

Mohammed K. Farouk, Major Professor

Date of Defense: November 2, 2011

The dissertation of Sergio Nieves is approved.

Dean Delia C. Garcia

College of Education

Dean Lakshmi N. Reddi

University Graduate School

Florida International University, 2011 
C Copyright 2011 by Sergio Nieves

All rights reserved. 


\section{DEDICATION}

This dissertation is dedicated to my family: Manuel Nieves, Dulce Nieves, and Jaqueline Capo, Jesus Rene Capo, Jesline Capo, and Jesus Rene Capo, Jr. I thank G-d everyday for providing me with a family that supports all of my endeavors. I love all of you.

I would also like to dedicate this dissertation to Concepcion Martinez. Thank you for being a true colleague and a magnificent friend. 


\section{ACKNOWLEDGMENTS}

I would like to express my deepest gratitude to my major professor, Dr.

Mohammed K. Farouk. You provided me with a wealth of knowledge and guidance that made this research possible. It was also a privilege to present with you at two conferences.

I was very fortunate to have an amazing group of professors to serve on my committee. Dr. Hilary Landorf, thank you for supporting me throughout my masters and doctoral programs. You have helped me become the academic I am today. Dr. Leonard Bliss, thank you for the long hours you devoted in helping me analyze the data. Great times. Dr. Aixa Perez-Prado, thank you for being there for me when I needed a committee member and for helping me with my research. In addition to my committee members, Dr. Linda Bliss provided me with an extraordinary amount of time helping me with the writing structure of my dissertation. Also, Caprila Almeida from the Office of Graduate Studies in the College of Education assisted me greatly with all of the steps I needed to complete in order to graduate. I am forever indebted to all of you.

My dissertation was inspired by the research of Judith Torney-Purta, Rainer Lehmann, Hans Oswald, and Wolfram Schulz. After I read the IEA Civic Education Study, I immediately knew the research question that I wanted to focus on for my dissertation. I would also like to thank Carole Hahn for taking the time to read my study and providing me with important feedback. It was truly an honor.

I want to thank my colleagues, students, and parents from the Young Women's Preparatory Academy for their support throughout my research. I wake up every morning happy to work in such an awesome educational environment. 
I want to thank the following families and friends for being there for me throughout all these years: the Hernandez family, the Encinosa family, the Calderon Family, the Lleonart family, the Arribas family, the Montero family, the Romano family, the Cantero Family, the Thomas family, the Abraham family, my padrino Jose Luis Gonzalez, Alain del Risco, Diubel Cruz, Eric Hernandez, Christine Cuesta, Iris Rodriguez, Mortimer Hechavarria, Tammy Calvo, David Calvo, Dylan Mobley, Herbert Herring, Guillermo Ramos, Jon Rehm, Nelson Gomez, Norberto Hernandez, my Mother Lodge Luz de America no. 255, and the Nieves and Abraham family living in Cuba.

I am also very grateful to have had such a wonderful group of principals, teachers, and especially students to take part in this study. Lastly, I want to thank Florida International University, Miami-Dade County Public Schools, John Doyle and Robert Brazofsky from the Division of Social Sciences and Life Skills for M-DCPS, Milagros Gonzalez from the office of Professional Development for M-DCPS and Dr. Tarek Chebbi from the office of Assessment, Research, and Data Analysis for M-DCPS.

This dissertation is the culmination of an amazing journey. It was a blessing to work with so many great people. 


\author{
ABSTRACT OF THE DISSERTATION \\ THE CIVIC ACHIEVEMENT GAP: A STUDY ON THE CIVIC KNOWLEDGE, \\ SKILLS, AND ATTITUDES OF HISPANIC STUDENTS IN MIAMI-DADE COUNTY \\ PUBLIC SCHOOLS \\ by
}

Sergio Nieves

Florida International University, 2011

Miami, Florida

Professor Mohammed K. Farouk, Major Professor

This study assessed the civic knowledge, skills, and attitudes of Hispanic eighth grade students in Miami-Dade County Public Schools (M-DCPS), Florida. Three hundred sixty one Hispanic students of Cuban (253), Colombian (57), and Nicaraguan (51) ancestry from 10 middle schools participated in the study. Two hundred twenty eight students were from low socio-economic status (SES) background, and 133 were of middle SES background. There were 136 boys and 225 girls. The International Association for the Evaluation of Educational Achievement Civic Education Student Questionnaire was used to collect data. The instrument assessed the students' civic knowledge, skills, and attitudes. Multivariate analysis of variance was used to test for differences in the civic knowledge, skills, and attitudes of participants based on ancestry, SES, and gender.

The findings indicated that there was no significant difference in the civic knowledge, skills, and attitudes of Hispanic eighth grade students that were of Cuban, Colombian, and Nicaraguan ancestry. There was no significant difference in the civic 
skills and in five of the civic attitude scales for students from low SES families compared to those from middle SES families. However, there was a significant difference in the civic knowledge and in the civic attitude concerning classroom discussions and participation based on SES. The civic knowledge of middle SES students was higher than that of low SES students. Furthermore, middle SES Hispanic students displayed a higher mean score for the civic attitude of classroom discussions and participation than low SES students. There was no significant difference in the civic knowledge and in five of the civic attitude scales between boys and girls. However, there was a significant difference in the civic skills and the civic attitude of support for women's rights between boys and girls. Hispanic girls displayed a higher mean score in civic skills than Hispanic boys. Furthermore, the mean score of civic attitude of support for women's rights for Hispanic girls was higher than that of Hispanic boys.

It was concluded that Cuban, Colombian, or Nicaraguan participants did not demonstrate differences in civic attitudes and levels of civic knowledge and skills that eighth grade students possessed. In addition, when compared to boys, girls demonstrated a higher level of civic skills and a greater support for women's rights and participation in politics and their roles in politics. Moreover, SES was demonstrated to be a key factor in the acquisition of civic knowledge, regardless of ancestry. 


\section{TABLE OF CONTENTS}

CHAPTER

PAGE

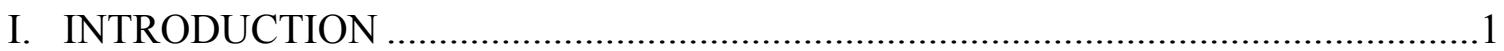

Statement of the Problem.................................................................................

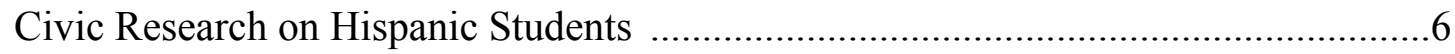

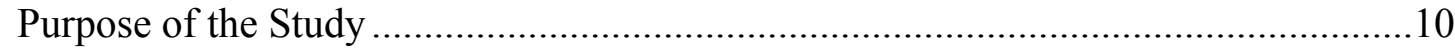

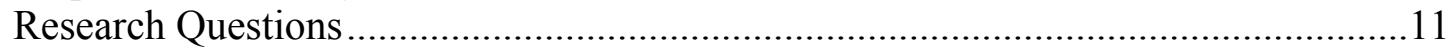

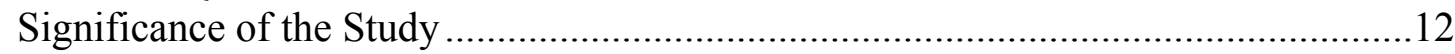

Are M-DCPS' Hispanic Students an Anomaly? ................................ 14

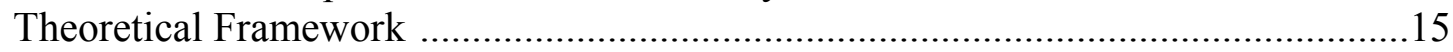

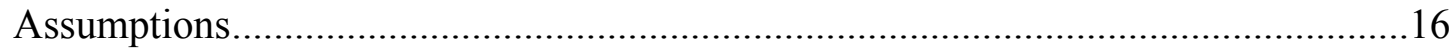

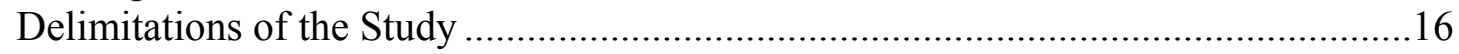

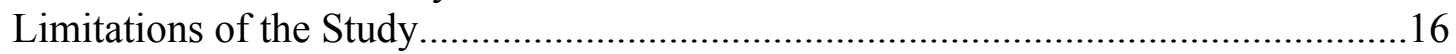

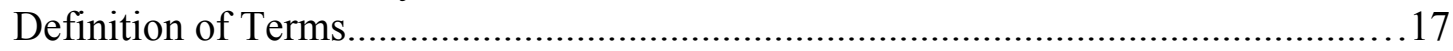

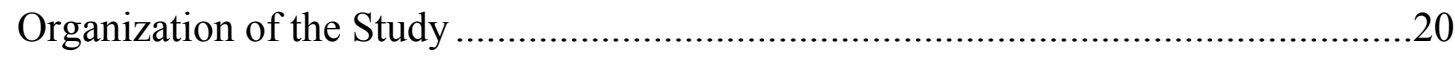

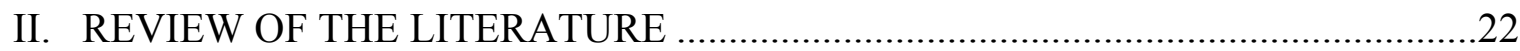

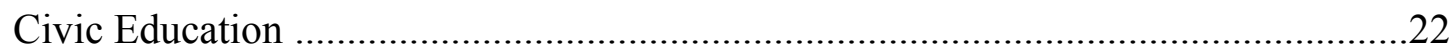

Civic Education in the United States ....................................................................2

The Civic Achievement Gap of Hispanic Students in the United States ....................28

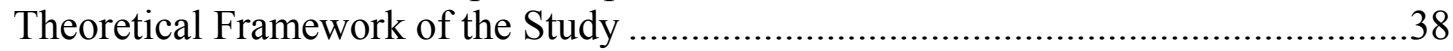

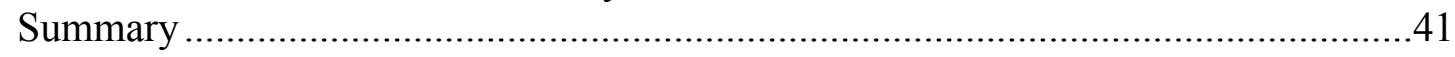

III. METHODS ............................................................ 42

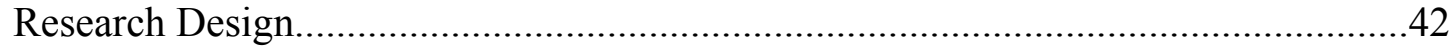

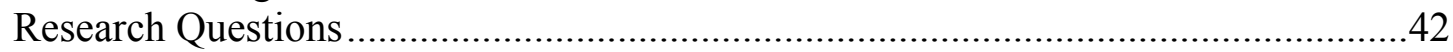

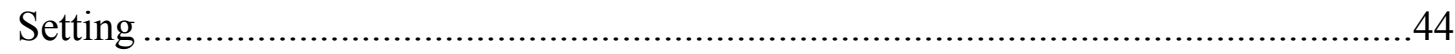

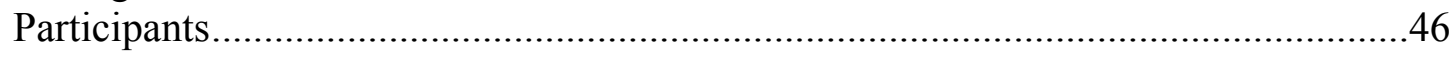

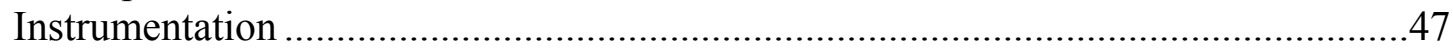

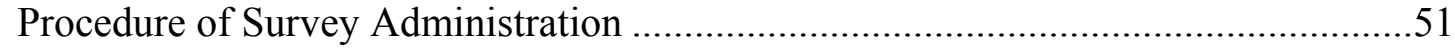

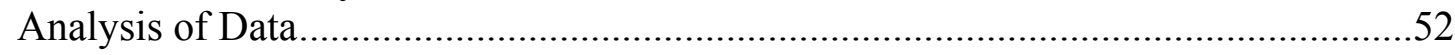

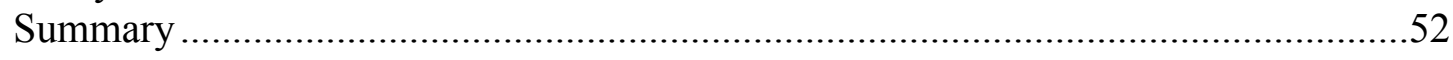

IV. RESULTS ............................................................ 54

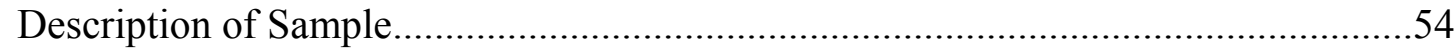

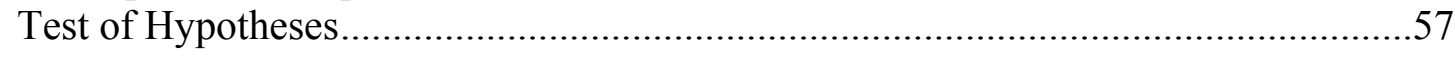

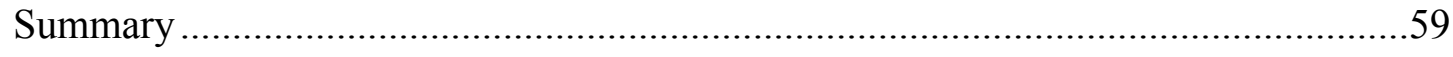

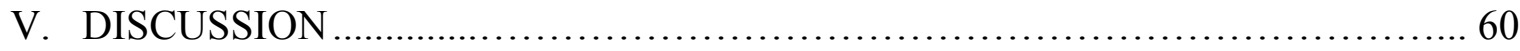




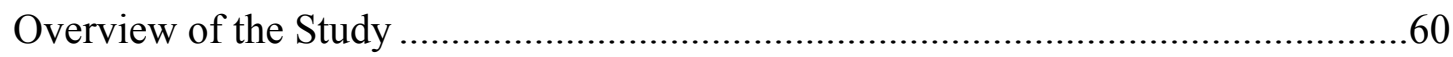

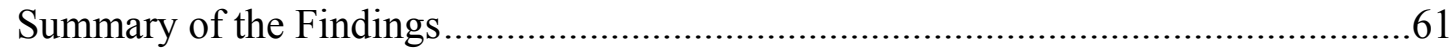

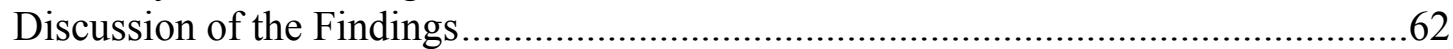

Conclusions, Implications, and Future Research .................................................. 70

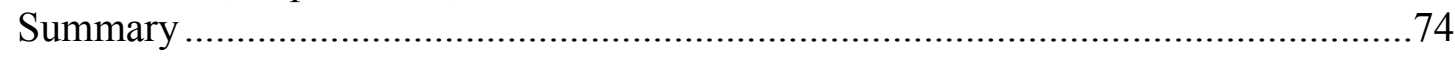

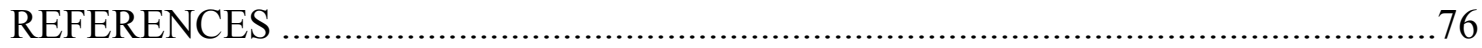

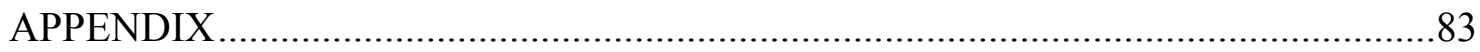

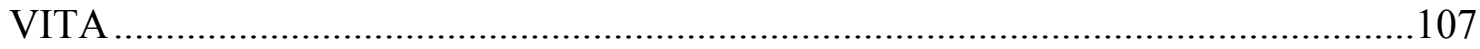




\section{CHAPTER I}

\section{INTRODUCTION}

Civics is the study of rights, duties, and responsibilities of residents and citizens. Civic education teaches students civic knowledge, skills, and attitudes with the goal of achieving competent and responsible citizens and residents. There has been a resurgence of research regarding the civic knowledge, skills, and attitudes of students in the past decade (Banks, 2008; Carnegie Corporation of New York and the Center for Information and Research on Civic Learning and Engagement [CIRCLE], 2003; Ichilov, 1998; National Council on the Social Studies [NCSS], 2001; Torney-Purta, 2000, 2002; Torney-Purta, Lehmann, Oswald, \& Schulz, 2001). The United States government has also shown a great deal of interest regarding the civic knowledge, skills, and attitudes of American public school students. Thousands of hours have been spent in meetings designing curriculum with the purpose of educating American public school students to achieve civic competence. Furthermore, millions of dollars have been spent on civic education and grants related to it (Bohan, 2003; Cogan, 1997; Paige, 2003).

Zill (2002) studied the civic attitudes of American high school students over the past 25 years by analyzing and comparing the research conducted by the National Institute on Drug Abuse (1975), the National Election Survey (1988 and 2000), and the National Household Education Survey (1996). His findings suggest that students in the year 2000 were not as politically astute and less likely to vote, write to their Congressperson, and participate in a lawful demonstration compared to students in 1975. Perhaps one of the most interesting comparisons Zill (2002) made in his research dealt with high school students and their beliefs about obeying the law. Thirty-six percent of 
students in 2002 agreed "that one of the hallmarks of good citizenship is always obeying the law"; however, "the size of this minority had diminished from $45 \%$ " since the same question was asked in 1977 (Zill, 2002, p. 28).

As a result of public schools students' lack of civic knowledge, skills, and attitudes, the United States government has implemented several initiatives and spent millions of dollars in grants. In 1994, the Clinton administration included in an education initiative titled Goals 2000 to improve the effectiveness of the civic education curriculum in the United States. This plan dealt with other subject areas as well, not just civics. The civics portion of Goals 2000 stated:

(3) STUDENT ACHIEVEMENT AND CITIZENSHIP. (A) By the year 2000, all students will leave grades 4, 8, and 12 having demonstrated competency over challenging subject matter including English, mathematics, science, foreign languages, civics and government, economics, arts, history, and geography, and every school in America will ensure that all students learn to use their minds well, so they may be prepared for responsible citizenship, further learning, and productive employment in our Nation's modern economy. (Goals 2000 Educate America Act, 1994)

Furthermore, the U.S. Department of Education has advocated and promoted the importance of civic education. The U.S. Department of Education under the Character and Civic Education (CCE) group awards grants to civic organizations and schools for the development of curricula and programs in civics education for elementary and secondary school students. For instance, the U.S. Department of Education provided a $\$ 16.9$ million grant to the Center for Civic Education to fund their projects such as the We the People Program (Paige, 2003).

Twelve years after the Goals 2000 initiative and 3 years after the multi-million dollar grant to the Center for Civic Education, the National Assessment for Educational Progress (NAEP) published the Nation's Report Card for Civics 2006. According to 
NAEP, "civics scores have remained essentially unchanged since 1998 for eighth and twelfth graders. In 2006, performance that is considered to be at or above the Proficient level was demonstrated by 22 percent of eighth graders and by 27 percent of twelfthgraders" (U.S. Department of Education, 2006, p. 6). Furthermore, the report provides a rationale as to why eighth grade students achieved lower scores in comparison to fourth graders. In middle school, less time is spent on definitions of civic life, politics, and government, and on the role of citizens. More time is spent on the foundations of the American political system, and the purposes, values, and principles of American democracy.

Levinson (2005) made the argument that schools are getting away from promoting democratic ideals. Instead, schools are creating an "economically competentor adaptable worker, not the democratic or intercultural citizen" (p. 329). Levinson (2005) pointed out that the United States is exporting to other countries its democratic ideals and principles through non-profit organizations such as the Center for Civic Education and Civitas International. However, according to Levinson (2005), "educators in other countries are typically less aware that the trend in U.S. public education has been to eschew a central commitment to educating democratic citizens" (p. 330).

Westheimer and Kahne (2003) point out that there is no consensus in the United States public school system regarding the meaning of civic education. According to the authors, public school students are "no more in agreement on what good citizenship means than are teachers, policy makers, and politicians" (Westheimer \& Kahne, 2003, p. $10)$. 


\section{Statement of the Problem}

The problem investigated in this study was to understand and address the civic achievement gap (Levinson, 2007) that exists among Hispanic students in the United States (Torney-Purta, Barber, \& Wilkenfeld, 2006, 2007). More specifically, the study assessed the civic knowledge, skills, and attitudes of eighth grade Hispanic students in Miami-Dade County Public Schools (M-DCPS) in Miami, Florida. To clarify, Hispanic is not a race. Hispanic is an ethnic group, which encompasses individuals of all races. When this study refers to White, Black, or Asian students, it is referring to non-Hispanic students.

According to Levinson (2007), the civic achievement gap refers to the rift that exists between "non-white, poor, and/or immigrant youth" and "white, wealthier, and/or native born youth" in gaining and understanding the "civic knowledge, skills, and attitudes necessary for taking effective civic and political action (p. 4). Levinson has made the argument that the civic achievement gap follows the student into adulthood. She has pointed to the fact that a voting gap exists based on race, ethnicity, and income and that minorities and people of low SES are cynical and mistrustful toward government. She believes that civic education has the ability to empower the students with the "skills, knowledge, and attitudes that will prepare them to be competent and responsible citizens throughout their lives" (p. 4).

CIRCLE and the Carnegie Corporation of New York (2003) published a report titled The Civic Mission of Schools. The report stated that "the overall goal of civic education should be to help young people acquire and learn to use the skills, knowledge, 
and attitudes that will prepare them to be competent and responsible citizens throughout their lives" (p. 10).

The report emphasized that competent and responsible citizens:

1. are informed and thoughtful. They have a grasp and an appreciation of history and the fundamental processes of American democracy; an understanding and awareness of public and community issues; an ability to obtain information when needed; a capacity to think critically; and a willingness to enter into dialogue with others about different points of view and to understand diverse perspectives. They are tolerant of ambiguity and resist simplistic answers to complex questions. 2. participate in their communities. They belong to and contribute to groups in civil society that offer venues for Americans to participate in public service, work together to overcome problems, and pursue an array of cultural, social, political, and religious interests and beliefs.

3. act politically. They have the skills, knowledge, and commitment needed to accomplish public purposes - for instance, by organizing people to address social issues, solving problems in groups, speaking in public, petitioning and protesting to influence public policy, and voting.

4. have moral and civic virtues. They are concerned for the rights and welfare of others, are socially responsible, willing to listen to alternative perspectives, confident in their capacity to make a difference, and ready to contribute personally to civic and political action. They strike a reasonable balance between their own interests and the common good. They recognize the importance of and practice civic duties such as voting and respecting the rule of law (p. 10). 
Levinson (2007) has supported CIRCLE and the Carnegie Corporation of New

York's (2003) definition of competent and responsible citizens. Levinson stated that:

In essence, good citizens need to be knowledgeable about politics, history, government, and current events; they need to be skilled communicators, thinkers, and deliberators; they need to be concerned about the common good in addition to their own self- interest, and to believe it is possible and worth trying to make a difference through public action; and they need to become involved in public or community affairs, through some combination of voting, protesting, contacting public officials, mobilizing others, contributing time or money to causes or campaigns, participating in community groups, and other appropriate actions. This is what it means to be a good citizen. (p. 5)

Civic education encompasses skills, knowledge, and attitudes that will prepare students to be competent and responsible citizens or residents throughout their lives (CIRCLE, 2003). However, according to Levinson (2007), many of America's youth are not developing the civic knowledge, skills, and attitudes mentioned above in the schools. She concluded that "there is evidence of a profound civic achievement gap between poor, minority, and immigrant youth and adults on the one hand, and middle-class, or wealthy, White, and native born youth and adults, on the other" (p. 5).

\section{Civic Knowledge of Hispanic Students}

Research on the civic knowledge of Hispanic students is limited (Torney-Purta et al., 2006). In this section, the civic knowledge of Hispanic students is briefly discussed. Civic knowledge refers to the students' knowledge of civic and democratic principles and institutions. It encompasses the students' understanding of the foundations of the American political system, the Constitution, the relationship of the United States to other nations and to world affairs, and the roles of citizens in American democracy (NAEP, 1998; Torney-Purta et al., 2001). 
In 1999-2000, the International Association for the Evaluation of Educational Achievement (IEA) conducted the Civic Education (CivEd) Study in which 29 countries and 140,000 adolescents participated. About 2,811 American ninth graders (approximately 14 years old) participated in the study. The study found that Hispanic non-immigrant students and Hispanic immigrant students had lower mean scores in civic content knowledge than non-Hispanic and non-immigrant students (Torney-Purta et al., 2006).

The Nation's Report Card for Civics in 2006 details unimpressive results of the civic knowledge of Hispanic students. According to NAEP, fourth grade Hispanic students and eighth grade Hispanic students demonstrated lower Civics scores than White students, Black students, and Asian students. Twelfth grade Hispanic students demonstrated lower Civics scores than White students and Asian students (U.S. Department of Education, 2006, p. 13).

Moreover, Hispanic students did not perform well in the Advanced Placement (AP) U.S. Government and Politics exam administered by the College Board. The exam is measured on a five points scale. Hispanic students' mean score was lower (Mexican American 1.9, Puerto Rican 2.17, and Other Hispanic 2.02) in comparison to White students (2.84), American Indian students (2.29), and Asian students (2.75; College Board Summary Reports, 2008).

\section{Civic Skills of Hispanic Students}

Civics teachers have the important task of educating students on civic skills such as interpreting political advertisements and political cartoons which are essential in order to make sense of civic-related information (Baldi et al., 2001). The IEA CivEd Study 
found that Hispanic students scored lower on interpreting political communication than non-Hispanic students (Torney-Purta, et al., 2006). However, it should be noted that the research on the civic skills of Hispanic students is limited (Torney-Purta, et al., 2006). Nevertheless, according to the literature, the schools are not effectively teaching civic skills to Hispanic students (Lopez \& Kirby, 2007; Kahne \& Middaugh, 2008; Levine, Lopez, \& Marcelo, 2006).

Lopez and Kirby (2007) analyzed the data from a survey conducted in 2006 by CIRCLE titled Civic and Political Health of the Nation Survey (CPHS). They found that "Latino students were the racial/ethnic group least likely to attend civics classes that encouraged them to make up their own minds about different political and social issues" (Lopez \& Kirby, 2007 p. 5). The same study also found that civics classes in which Hispanic and African American students were the majority covered less traditional topics such as the Constitution or the U.S. system of government and how it works, racism and other forms of injustice in American history, and problems facing the country today. Kahne and Middaugh (2008) employed the data from the IEA CivEd study to investigate the civic opportunities of high school students. In addition, the researchers utilized surveys from 2,500 California high school juniors and seniors. They observed that "Latino students reported fewer opportunities to participate in community service, simulations, and open classroom climates than White students" (p. 4).

In 2006, Levine, Lopez, and Marcelo examined the impact (if any) of the No Child Left Behind Act (NCLB) on the curriculum of the public schools. The authors found that "Many schools with predominantly minority student bodies reported cutting times for civics, social studies, and geography, although these trends were not evident in 
majority White schools" (Levine et al., 2006, p. 2). The time taken from the social studies courses were allocated to reading, writing, mathematics, and science (Levine et al., 2006).

\section{Civic Attitudes of Hispanic Students}

Research on the civic attitudes of Hispanic students is limited (Torney-Purta et al., 2006). Civic attitude refers to a person's intention and beliefs related to the government, civic issues, and the appreciation of human difference as well their inclinations toward serving others for the betterment of the common good (Torney-Purta et al., 2001). Furthermore, the current study also focused on the civic engagement attitudes of Hispanic students. Civic engagement attitudes are a subset of civic attitudes. It includes the students' interest in politics, which includes reading, listening, and watching the news as well as their expected participation in political activities (Torney-Purta et al., 2001). The IEA CivEd study found that Hispanic students express less positive attitudes about the nation compared to native-born and non-Hispanic students. The same study also reported that non-Hispanic students are more likely to expect to vote than Hispanic students (Torney-Purta et al., 2006).

Marcelo, Lopez, and Kirby (2007) examined data from the 2006 Civic and Political Health of the Nation Survey. Their research provided information on the civic engagement of youth (15-25 year olds) and confidence in government by race and ethnicity. The authors noted that Latinos reported the lowest volunteering rate at $29.5 \%$ as well at the lowest regular volunteering rate at $16.6 \%$. In comparison, Asian-American youth reported the greatest volunteering rate at $54.4 \%$ as well as the highest regular volunteering rate at $27.1 \%$. Furthermore, Latino youth feel the least effective in making 
a difference and influencing their community and the government (47.7\%) and they continue to register to vote at lower rates than African-American and White youth. However, the authors found that in the area of protest, young Latinos $(25.3 \%)$ were the most likely to have protested in the last year.

Foster-Bey (2008) conducted a similar study as the one conducted by Marcelo, Lopez, and Kirby (2007). The researcher used the 2005-2007 Current Population Survey's Annual Volunteer Supplement to measure the civic engagement of Whites, Blacks, Hispanics, and Asian adults. The author found that "Controlling for education and family income non-Hispanic Whites are least likely to drop out of civic activities from one year to the next, while Hispanics are most likely to discontinue civic activity" (Foster-Bey, 2008, p. 14). Foster-Bey (2008) also found that "being Latino relative to non-Latino reduces the odds of being a formal volunteer by $24 \%$ " (p. 9).

\section{Purpose of the Study}

This study assessed the civic knowledge, skills, and attitudes of Hispanic eighth grade students in M-DCPS. The United States has the second highest Hispanic population in the world with 46 million Hispanics (Mexico ranks first with 110 million). Even more impressive are the future population projections of Hispanics in the United States. According to the U.S. Census Bureau, the Hispanic population in the year 2050 will make up $30 \%$ of the U.S. population at over 130 million. One out of every four Americans will be of Hispanic ancestry (U.S. Census Bureau, 2009).

American public schools have also displayed the same population growth. The Pew Hispanic Center (2008) reported, “Hispanic students in the nation's public schools nearly doubled from 1990 to 2006 , accounting for $60 \%$ of the total growth in public 
school enrollments over that period" (p. i). The report also stated that approximately 10 million Hispanic students attend America's public schools accounting for 1 in 5 of the student population. Future projections of Hispanics in America's public schools are even more remarkable. The population of Hispanic students in the public schools will increase from 11 million in 2006 to 28 million in the year 2050. Furthermore, the same report predicted that "In 2050, there will be more school-age Hispanic children than school-age non-Hispanic White children" (Pew Hispanic Center, 2008, p. i).

Levinson (2007) asked in her study on the civic achievement gap of minority students, "Why do these data matter?" (p. 8). She replied to her own question by stating:

I suggest that anyone who believes in the value of democratic governance should recognize how crucial it is to narrow the gap. Individuals' civic knowledge, skills, and attitudes profoundly influence their civic and political behavior, and civic and political engagement, concomitantly, are central to the strength, stability and legitimacy of democracy...Governments that appear to (and/or do) serve the interests of only a narrow segment of the population cease to be viewed as democratic, and cease to inspire the loyalty and commitment of those who feel excluded or ignored. This poses a direct threat to both their legitimacy and stability. (pp. 8-9)

Given the demographic changes that have been projected, it is imperative to investigate the civic knowledge, skills, and attitudes of Hispanic students so that appropriate curricula can be developed to address any deficiencies or gaps that may exist. Moreover, NAEP does not provide a city-by-city comparison for the civics assessment as they do with other subject areas. Therefore, the researcher finds it necessary to assess and survey students from M-DCPS.

\section{Research Questions and Hypotheses}

The following research questions and null hypotheses were addressed in the study: 
1. Is there a significant difference in the levels of civic knowledge, skills, and the civic attitudes of Hispanic students who are of different nationalities (i.e., comparing students who are of Cuban, Colombian, and Nicaraguan ancestry)?

H1a. There is no significant difference in the level of civic knowledge of Hispanic students who are of different nationalities (i.e., comparing students who are of Cuban, Colombian, and Nicaraguan ancestry).

H1b. There is no significant difference in the level of civic skills of Hispanic students who are of different nationalities (i.e., comparing students who are of Cuban, Colombian, and Nicaraguan ancestry).

H1c. There is no significant difference in the civic attitudes of Hispanic students who are of different nationalities (i.e., comparing students who are of Cuban, Colombian, and Nicaraguan ancestry).

2. Do middle to high SES students score higher in tests of civic knowledge, skills, and civic attitudes in comparison to students of low SES?

H2a. There is no significant difference on tests of civic knowledge of Hispanic students who pay full price for lunch compared to students who receive free/reduced lunch.

$\mathrm{H} 2 \mathrm{~b}$. There is no significant difference on tests of civic skills of Hispanic students who pay full price for lunch compared to students who receive free/reduced lunch.

$\mathrm{H} 2 \mathrm{c}$. There is no significant difference in civic attitudes of Hispanic students who pay full price for lunch who pay full price for lunch compared to students who receive free/reduced lunch. 
3. Is there a significant difference in the levels civic knowledge, skills, and civic attitudes of Hispanic male students and Hispanic female students?

H3a. There is no significant difference in the level of civic knowledge of Hispanic male students and Hispanic female students.

H3b. There is no significant difference in the level of civic skills of Hispanic male students and Hispanic female students.

H3c. There is no significant difference in civic attitudes of Hispanic male students and Hispanic female students.

\section{Significance of the Study}

This study is significant to M-DCPS because it provided empirical evidence to support efforts to promote the teaching of an effective civic education program. In addition, this study will contribute to the literature on the civic knowledge, skills, and attitudes of Hispanic students in the United States.

One challenge in teaching civic education in M-DCPS comes from the fact that its student population represents 177 countries and territories. M-DCPS is the fourth largest school district in the United States. This school district has one of the most diverse student populations in the United States with over 200,000 Hispanic, 100,000 Black (which includes Haitians, Bahamians, Jamaicans, etc.) and 50,000 White students; in 2006-2007 over 50,000 students were enrolled in English Language Learner classes. Furthermore, $61 \%$ of the students qualify for free and reduced lunch (M-DCPS, 2007). In the 2008-2009 school year, the total number of students in the eighth grade (the grade that participated in the current study) was 26,286 , of whom $62 \%$ were Hispanic $(16,529$; M-DCPS, 2009). The instructional staff of M-DCPS also demonstrates the diversity of 
the county: 29\% are White non-Hispanic, $27 \%$ are Black non-Hispanic, and $42 \%$ are Hispanic, and $1.6 \%$ are Asian/American Indian.

Torney-Purta et al. (2006) in their study on the civic knowledge and attitudes of adolescents in the United States by immigrant status and Hispanic background stated that "In comparison with Caucasian and African American youth, Hispanic youth are less likely to report that voting is an important activity and most likely to view it as a choice rather than a responsibility" (p. 345). In addition, "Hispanic adolescents also have less trust in the government" (Lopez, 2003 as cited in Torney-Purta et al., 2006, p. 345). With over 200,000 Hispanic students, M-DCPS Social Studies teachers have to overcome this obstacle. The means to do so can be through an effective civic education curriculum (Torney-Purta et al., 2006).

Furthermore, Miami prides itself on being known as "The gateway to the Americas." Miami-Dade County's population is made up of immigrants from all over the world. As a result, M-DCPS is charged with the responsibility of teaching its immigrant student population the rights and responsibilities of being a resident or citizen of the United States as well as the importance of civic involvement. However, this is not an easy task. Many of Miami-Dade County's immigrant population originated from nations that are not democratic (e.g., Cuba) or are undergoing massive political changes (e.g., Bolivia, Colombia, Ecuador, Haiti, Honduras, and Venezuela). Moreover, due to political changes and uncertainty taking place in many Latin American nations such as Bolivia, Cuba, Nicaragua, Venezuela, and most recently Honduras, the number of students immigrating to Miami-Dade County will surely increase. As a result, M-DCPS 
has the important mission of teaching a large immigrant student population the rights and responsibilities of being a citizen or resident in the United States.

\section{Are M-DCPS' Hispanic Students an Anomaly?}

NAEP recently released the results of the 2009 mathematics and reading assessment. The results of the NAEP 2009 mathematics and reading assessment illustrate that M-DCPS fourth and eighth grade Hispanic students outperformed the majority of Hispanic students in the largest school districts in the U.S. Fourth grade Hispanic students from M-DCPS had the highest average score (239) in mathematics from the 17 cities that met the reporting standards of the NAEP study. Houston and Charlotte were tied for second with the second highest average score (235). Eighth grade Hispanic students from M-DCPS were tied for second with Austin in the mathematics assessment with an average score of 274. Houston had the highest average score (275; U.S. Department of Education, 2009).

Fourth grade Hispanic students from M-DCPS had the highest average score (224) in reading from the 15 cities that met the reporting standards of the NAEP study. Charlotte had the second highest average score (212). Eighth grade Hispanic students from M-DCPS had the highest average score in the reading assessment with an average score of 261. Charlotte had the second highest average score (254; U.S. Department of Education, 2009).

The researcher wanted to build up on the momentum created by the results of the 2009 NAEP mathematics and reading assessment. M-DCPS superintendent Alberto Carvalho acknowledged the educational performance of Hispanic students from the 
district: "This is a very special accomplishment for our children. They are learning at a higher level than any other Hispanic children in the country" (Mazzei, 2009, para. 17).

\section{Theoretical Framework for the Study}

This study is based on the theoretical framework of the Octagon model of the IEA CivEd study. This theoretical framework was chosen for the reason that the model acknowledges and addresses the various societal influences and factors that shape the individual student's identity in the community and political environment (Torney-Purta et al., 2001).

The societal influences and factors are depicted on the outside of the Octagon model, which include religion, politics, economics, and education as well as "the country's position internationally, the symbols or narratives important at the national or local level, and the social stratification system, including ethnic and gender-group opportunities" (Torney-Purta et al., 2001, p. 23). The inside of the Octagon model reflects the day-to-day encounters that impact the individual student such as "family (parents, siblings, and sometimes extended family), school (teachers, implemented curriculum and participation opportunities), peer group both in and out of class, and neighbors (including people in out-of-school youth organizations" (Torney-Purta et al., 2001, pp. 22-23). In addition, the Octagon model of the IEA CivEd study was the theoretical framework for two of the most comprehensive studies that have taken place to this day regarding the civic knowledge and engagement of students (Amadeo et al., 2002; Torney-Purta et al., 2001).

\section{Assumptions}

The basic assumptions of this study are: 
1. The teachers are teaching the required civic education curriculum mandated by M-DCPS.

2. The teachers have been either trained or have taken college courses that will aid them in teaching the civic education curriculum.

3. Civics education is important in teaching students to be competent and responsible citizens.

\section{Delimitations of the Study}

Only eighth grade middle school students enrolled in U.S. History participated in the study. In addition, only public schools were chosen for the study. This study did not assess and survey students from private, religious, or charter schools in Miami-Dade County. Therefore, assumptions cannot be made regarding the civic knowledge, skills, and attitudes of Hispanic students from charter, private, and religious schools.

\section{Limitations of the Study}

The instrument was only administered in English. Therefore, the knowledge of English the students possessed as well as the academic language used in the instrument could hinder an English Language Learner (ELL) student in understanding the questions being asked. In addition, the interpretation of political cartoons presented in the instrument might be a limitation to a foreign-born student whose native country portrays political cartoons in a different context than the one in the United Sates. Furthermore, MDCPS does not identify students by their ancestry. In other words, students of Cuban, Colombian, or Nicaraguan ancestry who are born in the United States are identified as Hispanic by M-DCPS but their ancestry is not identified. M-DCPS only identifies the ancestry of foreign-born students. 


\section{Definition of Terms}

The following terms and concepts are defined for the purpose of this study:

Academic achievement. Academic achievement refers to a student's grade point average (GPA), ACT scores, SAT scores, Advanced Placement scores, or state-mandated test scores.

Ancestry. Ancestry refers to a person's self-identification of heritage, ethnic origin, descent, or close identification to an ethnic group (U.S. Census Bureau, 2010).

Civics. Civics is the study of the rights, duties, and responsibilities of citizens and residents.

Civic achievement gap. The disparity that exists between minorities and students of low SES status and students who are White and of a higher SES in civic knowledge, skills, and civic attitudes necessary for taking civic and political action (Levinson, 2007).

Civic attitude. Civic attitude refers to a person's intention and beliefs related to the government, civic issues, and the appreciation of human difference as well their inclinations toward serving others for the betterment of the common good. The IEA CivEd study measured the civic attitude of students regarding civic issues such as trust in government-related institutions, their perception of how much citizens can influence government decisions, and their support for the rights of immigrants and women (Torney-Purta et al., 2001).

Civic competence. The knowledge, skills, and attitudes required of students to be able to assume the "office of citizen" in our democratic republic (NCSS, 1992). 
Civic education. Civic education teaches students the skills, knowledge, and attitudes that will prepare them to be competent and responsible citizens or residents throughout their lives (CIRCLE, 2003).

Civic engagement attitudes. Civic engagement attitudes include the students' interest in politics, which includes reading, listening, and watching the news as well as their expected participation in political activities (Torney-Purta et al., 2001).

Civic knowledge. Civic knowledge refers to the students' knowledge on civic and democratic principles and institutions (Torney-Purta et al., 2001).

Civic skills. Civic skills refer to the interpretive skills needed to make sense of civic-related information such as the skills needed to interpret a newspaper article or a political cartoon (Baldi et al., 2001). Civic skills also encompasses gathering, interpreting, analyzing, summarizing, evaluating and presenting information; categorizing information; establishing cause and effect relationships; understanding issues, their history and contemporary relevance; identifying, describing, evaluating, and defending a position; and identifying criteria for making judgments (Constitutional Rights Foundation, 2010).

Effective civic education program. An effective civic education program should "consciously promote civic engagement by all students, with special attention to those who might otherwise be disengaged; give students opportunities to contribute opinions about the governance of the school—not just through student governments, but in forums that engage the entire student body or in smaller groups addressing significant problems in the school; help students to understand how their own schools and school systems are run, who makes the policies that affect them, and what issues are being 
debated by local educational leaders and the community; collaborate with the community and local institutions to provide civic learning opportunities; provide teachers with access to professional development in civic education, foster collaboration and networking, and recognize teachers who are doing good work in this area; infuse a civic mission throughout the curriculum; offer an array of extracurricular activities; and structure the school environment and climate so that students are able to "live what they learn" about civic engagement and democracy" (CIRCLE, 2003, p. 21).

Hispanic/Latino. This study used the U.S. Census Bureau's definition of Hispanic. The federal government considers race and Hispanic origin to be two separate and distinct concepts. Hispanic is not a race. Hispanic is an ethnic group, which encompasses individuals of all races. When this study refers to White, Black, or Asian students, it is referring to non-Hispanic students. Furthermore, according to the Census Bureau, persons of Hispanic origin are those who indicated that their origin was Mexican, Puerto Rican, Cuban, Central or South American. Brazilians or people of Portuguese descent are excluded from this definition (U.S. Census Bureau, 2009). The U.S. Census Bureau uses Hispanic and Latino interchangeably. Therefore, the two terms were also used interchangeably in this study (Office of Management and Budget, 2009).

Social Studies. Social Studies is the integrated study of the social sciences and humanities to promote civic competence (NCSS, 1992).

\section{Organization of the Study}

Chapter 1 has presented the purpose, problem and significance of assessing the civic knowledge, skills, and attitudes of Hispanic middle school students in M-DCPS in Miami-Dade County, Florida. This chapter also contains the research questions, 
theoretical framework, assumptions, limitations, and definitions of terms. Chapter 2 presents the review of the literature that provides relevant research pertaining to civic education in the United States and the civic achievement gap of Hispanic students in the United States. In addition, the theoretical framework of the study is also presented. Chapter 3 presents the methods and data utilized in the study. This chapter provides a detailed explanation of the instrument (the International Study of Civic Education Student Questionnaire) used to answer the research questions. This chapter also provides information regarding the setting and the participants of the study. In Chapter 4, the results of the statistical analyses of the data collected are presented. Chapter 5 discusses the results of the statistical analyses and brings forth the conclusions, implications, and recommendations for future research. 


\section{CHAPTER II}

\section{REVIEW OF THE LITERATURE}

This chapter provides a review of the literature regarding civic education in the United States. Literature concerning the civic achievement gap of Hispanic students in the United States was also examined. The chapter is organized into three major sections: civic education in the United States, the civic achievement gap of Hispanic students in the United States, and the theoretical framework for the study.

\section{Civic Education}

Civic education teaches students the knowledge, skills, and attitudes that will prepare them to be competent and responsible citizens or residents throughout their lives (CIRCLE, 2003). Research on civic education continues to be of great interest to researchers and scholars (Banks, 2008; Mitchell \& Parker, 2008; Parker, 2008). In addition, due to the growth in the number of democratic nations in various regions of the world such as Latin America and Eastern Europe, interest in studying civic education internationally has increased (Hahn \& Alviar-Martin, 2008). In the United States, research pertaining to civic education in the schools becomes of great interest after national catastrophes. Hepburn (1990) noted that in the Cold War era, there was an interest in reforming the civic education curricula as a means of warding off communism. Following the September 11, 2001 terrorist attacks, civic education came out of the shadows after more than a decade of not being of great concern to researchers due to the fall of the Soviet Union and the end of the Cold War (Abowitz \& Harnish, 2006). The following section of the literature review addresses a few theoretical frameworks pertaining to civic education. 


\section{Civic Education in the United States}

The following section is not intended to be an exhaustive review of the literature concerning civic education in the United States. Rather, the following review of the literature is focused on some of the disagreements regarding civic education as well as its need and importance in developing competent and responsible citizens and residents.

Parker (2008) stated that the democratic civic education curriculum in any given country addresses a few critical questions: "What outcomes are desired, and what is the plan for reaching them? Put differently, what kind of citizens do we want schools to cultivate, and how might these organizations go about that work?” (p. 65). Parker (2008) believes that the citizenry of a democratic nation should be enlightened and engaged. Furthermore, Parker (2006) believes classroom discussions, in which teachers and students are open to differences of opinion, can lead to enlightenment and engagement.

Parker (2001) acknowledged that civic education "is a remarkable and daring undertaking" due to the fact that the citizen identity does not develop because of age and the school system is not the only factor in molding citizens (p. 6). A problem that arises with civic education is the fact that the concept of citizenship varies from nation to nation (Lee, 2002). Furthermore, according to Abowitz and Harnish (2006) the idea of citizenship changes with the times. The authors argued that, "citizenship is not a 'natural' idea but an invented concept that shifts with economic, political, and social changes" (p. 654). 
According to NCSS, an effective civic education program ensures that:

1. Civic knowledge, skills, and values are taught explicitly and systematically at every grade level. School and classroom management and culture exemplify and demonstrate core democratic values.

2. Citizenship education is integrated throughout and across the curriculum.

3. Students have meaningful opportunities to participate in class and school governance.

4. All students at every grade level are provided with opportunities to participate in the civic life of their school and community.

5. Learning activities extend beyond the school and invite parents and the community to participate and work with students.

6. Students are provided with opportunities to participate in simulations, servicelearning projects, conflict resolution programs, and other activities that encourage the application of civic knowledge, skills, and values.

7. All students are provided with instruction on our nation's founding documents, civic institutions, and political processes.

8. All students are provided with instruction on the people, history, and traditions that have shaped our local communities, our nation, and the world.

9. Preparing students to be effective citizens is explicitly recognized as an important part of the school mission. (NCSS, 2001, para. 10)

Parker (1996) illustrated in his study the struggles that are occurring within the United States that have impeded the development of a meaningful civic education curriculum. According to Parker (1996): 
There is a democratic education problem in the United States. The young are not learning properly to care for the body politic and the body politic is not adequately caring for the young. If parents, citizens, and educators are to grapple with the problem successfully, it will be necessary, among other things, to take a fresh look at an old idea in American education - democratic education. (p. 104)

Perliger, Canetti-Nasim, and Pedahzur (2006) illustrate in their study the disagreement that exists among scholars on the impact of civic education. The authors state that there are two major schools of thought concerning civic education. The first school of thought states that "relationships between civic studies and pupils' democratic attitudes are often negligible" (Perliger et al., 2006, p. 121). The second school of thought states that there are "clear correlations between civic studies and the internalization of democratic attitudes and behaviors" (Perliger et al., 2006, p. 121).

Parker (2005) believes that schools are a vital mechanism to deter idiocy. He sees idiocy as referring to a person that is occupied with private things rather caring about the common good. In the same study, Parker (2005) asserts that schools are able to develop public citizens (those that care about the community) and prevent private citizens (those that only care about private gain).

Decades earlier, Oppenheim and Torney (1974) emphasized the importance of civic education in transmitting to the students the nation's values:

Civic education does not merely consist in the transmission of a body of knowledge...it aims at inculcating certain shared attitudes and values, such as a democratic outlook, political responsibility, the ideals of tolerance and social justice, respect for authority, and so on...Indeed, the cognitive content of the curriculum is frequently used in order to highlight the underlying principles and ideology. (p. 13)

However, Pepper, Burroughs, and Groce (2003), Braungart and Braungart (1998), Westheimer and Kahne (2003), and Leming (2001) make the argument that the United States lacks structure, organization, and accountability in civic education. Westheimer 
and Kahne (2003) noted that there is no consensus in the US public school system regarding the goals of civic education. Public school students are "no more in agreement on what good citizenship means than are teachers, policy makers, and politicians" (Westheimer \& Kahne, 2003, p. 10). Leming (2001) argues that schools are teaching abstract concepts that are hard to define. The author states that "if the values remain at a high level of abstraction it is questionable how they can serve as a guide to action for students or teachers" (Leming, 2001, p. 73).

Although Leming (2001) makes the argument that schools are not clearly presenting their role of transmitting the democratic values of the nation, the importance of schools in evoking the students' ability to be competent and responsible cannot be understated. Furthermore, according to Yates and Youniss, (1998) adolescence is an important time for civic and political development.

McIntosh et al. (2007) utilized National Household Education Survey (NHES) data to see if a correlation exists between students taking civics courses and participation in youth activities resulted in higher levels of civic knowledge. The authors found that the number of civics courses taken and participation in youth activities such as student government were related to higher levels of civic knowledge. Lay (2006) also found that students that take civics courses have higher levels of civic knowledge compared to students that do not take any civics courses.

Although a correlation exists between civic knowledge and taking a civics course, according to Branson (2003) and Torney-Purta (2002), one civics course cannot be the only means of effectively teaching students to be competent and responsible citizens. According to Branson (2003), 
Those essential components of civic education cannot be accomplished in the one or two hours per week that many schools allot to learning for citizenship. Neither can they be achieved in a single cram course at the end of secondary school. (p. 9)

Torney-Purta (2002) proposed three ways through which schools can effectively promote civic education, which in turn will enhance the civic knowledge, skills, and attitudes of students. First, schools need to establish a formal civic education curriculum. Second, teachers need to promote a classroom culture that encourages discussion and debates that allow students to openly discuss their views in a respectful manner. Lastly, the school culture should provide opportunities for students to actively participate in a civic manner through organizations such as student government.

The classroom also plays an important role in developing students' civic knowledge, skills, and attitudes. Torney-Purta et al. (2007) found that classrooms that openly discuss political topics can increase students' civic knowledge as well as their voting intentions. Furthermore, Levine and Lopez (2004) found that students who choose to take civics classes are much more likely than other young people to report that:

1. they helped solve a community problem,

2. they can make a difference in their community,

3. they have volunteered recently,

4. they trust other people and the government,

5. they have made consumer decisions for ethical or political reasons,

6. they believe in the importance of voting, and

7. they are registered to vote (p. 5). 


\section{The Civic Achievement Gap of Hispanic Students in the United States}

According to the U.S. Census Bureau (2009), in the 2007-2008 school year, 20\%

of the students in elementary and secondary schools were of Hispanic origin. It is interesting to note that although Hispanic students make up a large percentage of the American student body, research pertaining to the civic knowledge, skills, and attitudes of Hispanic students is limited (Torney-Purta et al., 2007). As a result, the subsequent sections of this chapter consist of a review of the literature pertaining to Hispanic students in middle and high school as well as research pertaining to the academic achievement of Hispanic students.

The following sections focus on the civic achievement gap (Levinson, 2007) of Hispanic students in the United States. It is divided into three sections: the civic achievement gap of Hispanic students based on ancestry, the role of SES in the civic achievement gap of Hispanic students, and the role of gender in the civic achievement gap of Hispanic students. Although the research is limited, the findings suggest that the civic achievement gap of Hispanic students is greater than that of non-Hispanic students (Kahne \& Middaugh, 2008; Torney-Purta et al., 2006, 2007).

\section{The Civic Achievement Gap of Hispanic Students Based on Ancestry}

Research regarding the civic achievement gap differences among students of Hispanic ancestry is limited. The limited research that does exist tends to focus only on one group such as Mexican-American elementary school children (Griggs \& Dunn, 1996) or they group all Hispanics into one group (Wrinkle, Stewart, Polinard, Meier, \& Arvizu, 1996). Ancestry refers to a person's self-identification of heritage, ethnic origin, or close identification to an ethnic group (U.S. Census Bureau, 2010). In addition, the researcher 
included a research question to determine if there is a significant difference in the civic knowledge, skills, and attitudes amongst students of different Hispanic ancestry.

Two Latin American nations, Chile and Colombia, participated in the IEA CivEd Study (Amadeo, Torney-Purta, Lehmann, Husfeldt, \& Nikolova, 2002; Torney-Purta et al., 2001). The results of the IEA CivEd study showed that only half of the students in Chile correctly answered a question about who should govern in a democracy. Many Chilean students chose the incorrect answer that experts in politics ought to govern rather than the correct answer, popularly elected officials. Colombian students performed poorly when questions focused on dictatorships, non-democratic government, and on the rights of citizens to dissent. Chilean students also scored very poorly when questions required understanding threats to democracy. The results of the IEA CivEd study also showed that youth in Colombia and Chile did not trust their national government institutions (Reimers, 2007).

The results of the IEA CivEd study prompted Chile and Colombia to rethink their national standards and curriculum (Reimers, 2007). In addition, the study even influenced countries that did not participate in the study, such as Mexico. Many countries in Latin America have placed civic education as a top priority with a goal to increase the civic knowledge of the students (Reimers, 2007).

However, according to Reimers (2007):

There is little evidence that teacher practice and school culture are aligned with this goal. Even in contexts where the curriculum now explicitly focuses on developing democratic citizenship skills and knowledge, the daily experiences of students in schools frequently are of a different character. Teachers mediate the impact of changed curricula in their instructional practice. What teachers do is a function of their knowledge, beliefs, and competencies, as well as the incentives they face and the institutional culture and norms in which they work. For example, curricula emphasizing gender equity are meaningless in contexts where 
gender discrimination to staff or students is the rule. Schools where corruption takes place (including frequent unjustified teacher absenteeism, union intervention to prevent sanction of unprofessional performance, or charging illegal fees to enroll students) teach students forms of interaction inconsistent with democracy as a way of life. As a result, citizenship education is often disassociated from actual experience... Part of the challenge is that teachers themselves live in a context where a significant number of adults hold views that are lukewarm about democratic institutions and practices. (p. 12)

Reimers' (2007) view of adults having "lukewarm" feelings about democracy and its practices are quantitatively represented in the annual Latinobarometro poll (The Economist, 2009). The Latinobarometro poll measures the democratic beliefs of the citizens of 18 countries every year since 1995 . Since the focus of the research study is Hispanics, the results from Brazil are not included in the analysis. The 2009 poll consisted of 20,204 face-to-face interviews. The Economist (2009) compared the survey results from 1996, 2001, and 2009. The Economist stated that "Despite the recession which rippled across the region over the past year, Latin Americans are more supportive of — and satisfied with — their democracies and their governments...Support for democracy is at its highest level since the late 1990s, up 11 points from its trough in 2001" (para. 3). However, these improvements should not be viewed as a milestone. The poll asked two important questions concerning the respondents' preference towards a democratic government or an authoritarian government: "Which of the following statements do you agree with the most? Democracy is preferable to any other type of government" and "In certain circumstances, an authoritarian government can be preferable to a democratic one" (The Economist, 2009, chart 1).

The citizens of nine countries, Honduras, Chile, Guatemala, Peru, Mexico, Nicaragua, Paraguay, Colombia, and Ecuador, have less than a $60 \%$ preference for democracy over any other type of government. Furthermore, Colombia and Ecuador had 
a double-digit decrease in its citizens preferring democracy to any other type of government. Perhaps even more alarming is the fact that four countries, Guatemala, Dominican Republic, Paraguay, and Ecuador, have at least $20 \%$ of their citizens believing that in certain circumstances, an authoritarian government can be preferable to a democratic one.

Educators, educational researchers, and school districts (for the purpose of the current study, M-DCPS) should not ignore the findings of the Latinobarometro. The poll revealed that there is very limited support for democracy as a form of government. As of October 2007, over 20,000 students in M-DCPS are foreign born students from the nine countries listed in the previous paragraph that have less than a $60 \%$ preference to democracy over any other type of government: Chile 711 students; Colombia 6,828 students; Ecuador 1,159 students; Guatemala 682 students; Honduras 3,298 students; Mexico 2,306 students; Nicaragua 2,499 students; Paraguay 93 students; and Peru 2,629 students (M-DCPS, 2008).

An additional challenge for school districts with Hispanic immigrant students (such as M-DCPS) is the fact that many of these students do not come from "Full Democracies" (The Economist, 2008). According to The Economist (2008) Intelligence Unit's Index of Democracy report, only two Latin American countries are considered "Full Democracies": Uruguay (ranked 23) and Costa Rica (ranked 27). The report (The Economist, 2008) also found that the majority of Latin American nations have a "Flawed Democracy": Chile (ranked 32); Panama (ranked 43); Mexico (ranked 55); Argentina (ranked 56); Colombia (ranked 60); Paraguay (ranked 66); El Salvador (ranked 67); Peru (ranked 70); Dominican Republic (ranked 73); Honduras (ranked 74); Bolivia (ranked 
75); Nicaragua (ranked 78); and Guatemala (ranked 79). In addition, two countries, Ecuador (ranked 88) and Venezuela (ranked 95) are "Hybrid Regimes", which are countries that contain both democratic and authoritarian characteristics. The Latin American country with the lowest democratic ranking was Cuba (ranked 125). The Economist (2008) placed Cuba in the "Authoritarian" government group.

The above-mentioned findings should have major implications on the design and implementation of the civics education curricula for school districts (e.g. Miami-Dade County Public Schools) with large Hispanic immigrant student populations. According to M-DCPS (2008), 17.4\% of the student population (over 60,000) are foreign born students representing 18 Latin American nations: Argentina 2,774 students; Bolivia 242 students; Chile 711 students; Colombia 6,828 students; Costa Rica 520 students; Cuba 27,715 students; Dominican Republic 2,355 students; Ecuador 1,159 students; El Salvador 714 students; Guatemala 682 students; Honduras 3,298 students; Mexico 2,306 students; Nicaragua 2,499 students; Panama 387 students; Paraguay 93 students; Peru 2,629 students; Uruguay 703 students; and Venezuela 5,010 students (M-DCPS, 2008). Only two percent of the Hispanic immigrant student population in M-DCPS comes from full democracies (Costa Rica and Uruguay). As stated earlier, M-DCPS does not identify the students by their ancestry. In other words, students of Cuban, Colombian, or Nicaraguan ancestry that are born in the United States are simply identified as Hispanic by M-DCPS. M-DCPS only identifies the ancestry of foreign-born students.

\section{The Role of SES in the Civic Achievement Gap of Hispanic Students}

Research regarding the role of SES in the civic achievement gap Hispanic students is limited. Nevertheless, the research that does exist exhibits the need to study 
the civic achievement gap amongst Hispanic students of varying SES. According to Fry and Gonzales (2008), $28 \%$ of Hispanic students live in poverty whereas only $11 \%$ of nonHispanic White students live in a poor household.

Kahne (2009) found that students attending schools in which the majority of the students are from high SES backgrounds received better civic learning opportunities than students attending schools in which the majority of the students come from low-income families. Kahne (2009) also reported that students from higher income classrooms were "2 times more likely than students in average classroom average income levels to report studying the law; 2 times more likely to report participating in service activities; and $80 \%$ more likely to take part in panel discussions or debates" (p. 29). Furthermore, the study reported that Latino students "had fewer chances to participate in structured community service" as well as "fewer opportunities to participate in simulations of civic processes" such as debates (Kahne, 2009, p. 29). Furthermore, Kahne and Middaugh (2008) stated in their study that high school students attending higher SES schools, those who are college-bound and White students receive more classroom-based civic learning opportunities than low-income students, those not heading to college, and students of color. The authors also found that SES plays a role within the school in how likely students are to report civic opportunities: "students with an SES score a standard deviation higher than their class average were more than twice as likely to report experiences with volunteer work to help the community as were students with SES at their class average" (Kahne \& Middaugh, 2008, p. 16).

Hutchens and Eveland (2009) examined the long-term impact of high schools civics curricula on political knowledge, democratic attitudes, and civic behaviors. The authors 
utilized data of a longitudinal study of high schools within the Columbus Public School district of Columbus, Ohio. They found that schools with higher economically disadvantaged students displayed lower mean scores on factual knowledge and participation. Moreover, the mean score for cynicism was higher for the economically disadvantaged students.

Wilkenfeld's (2009) research yielded similar findings. The author utilized the data from the IEA CivEd study to examine the civic engagement of adolescents. Wilkenfeld's (2009) study indicated that "schools with a high-SES population are associated with higher civic knowledge even after the individual's own SES has been taken into account" (p. 5). Hahn (2001b) also utilized the data from the IEA CivEd study and found that "Students who attend schools in which more than 25 percent of their students are eligible for the free and reduced lunch program did less well on the achievement measures (skills, content, and overall knowledge) than did students in schools with fewer than 25 percent of their students eligible for the program" (p. 457).

Foster-Bey (2008) utilized the data the 2005-2007 Current Population Survey's Annual Volunteer Supplement to determine "whether certain disadvantaged socioeconomic groups are under-represented in volunteering and civic engagement as the research suggests" (p. 2). The author's findings concur with the literature that SES is an important predictor of civic engagement. Foster-Bey (2008) found that "Lower SES individuals seemed less civically-engaged than individuals from higher SES group" (p. 16).

The results of the NAEP (2006) civics test for eighth graders present the civic achievement gap among students of varying SES backgrounds. Regardless of race, 
students that were not eligible for the National School Lunch Program (i.e. students with a higher SES) outperformed students that qualified for either reduced or free lunch (160, 142 , and 140, respectively). Hispanic students that were not eligible for the National School Lunch program averaged 142 in the eighth grade civics exam whereas Hispanic students that were eligible for the National School Lunch Program displayed a higher civic achievement gap with an average score of 126. NAEP did not study the effect SES had on the civic knowledge of $12^{\text {th }}$ graders.

\section{The Role of Gender in the Civic Achievement Gap of Hispanic Students}

Research regarding the civic achievement gap differences between Hispanic male and female students is limited (Montoya, 1996). As a result, the following section includes research that pertains to other academic areas. Furthermore, the research that does exist fails to disclose pertinent information: for example, the city in which the study was conducted or the breakdown of the nationalities of the Hispanic students. In addition, many of the studies did not have a diverse student body representing several Hispanic nationalities. M-DCPS Hispanic student body represents all Latin American nations.

In the past two decades, Hispanic females are outpacing Hispanic males in high school and college graduation rates (Cammarota, 2004; Saenz \& Ponjuan, 2008). The National Center for Education Statistics (NCES, 2009) studied high school dropout and completion rates in the United States. The NCES data revealed that Hispanic males $(24.7 \%)$ were more likely to be high school dropouts than Hispanic females (18\%).

According to a study conducted by Sullivan, Riccio and Reynolds (2008) on the attitudes of students toward school and teachers, males reported more negative attitude 
towards both school and teachers than females. Akos and Galassi (2004) focused on the role of gender and race as a variable in psychosocial adjustment to middle school and high school. The result of their study demonstrated that girls felt more connected to school than did boys after transition to middle school. However, the opposite occurred during the transition to high school. Boys felt more connected to high school than did girls.

In the past few years, several researchers have focused on achievement gap differences that exist between male and female students (Cammarota, 2004; Foster-Bey, 2008; Sullivan, Riccio, \& Reynolds, 2008). In a study conducted by Sanchez, Colon, and Esparza (2005), Hispanic female students have higher grade point average (GPA) than Hispanic male students. Furthermore, their study found that Hispanic female students have higher educational aspirations and expectations than male Hispanic students. Their study, however, did not state the exact location of the school. The authors described it as a "Midwestern public high school" (p. 621). Furthermore, the majority of Hispanic students in the study were of Mexican (48\%) or Puerto Rican (40\%) origin.

Valencia and Johnson's (2006) research on the academic aspiration of seventh $12^{\text {th }}$ grade Latino students from 10 different counties in North Carolina yielded similar results to the study conducted by Sanchez, Colon, and Esparza (2005). Their research found that "Females reported a desire to do well in school (29\%) and a desire to be successful (29\%) more frequently than males (17\% and 19\%, respectively). Similarly, females reported professional career aspirations more frequently (85\%) than males (69\%)" (p. 359). However, Valencia and Johnson (2006) did not state the Hispanic nationalities of the students that participated in the study nor their SES backgrounds. 
Davila and Mora (2007b) analyzed data from the National Education Longitudinal Study (NELS) of 1988 to determine the civic engagement of high school students based on race, ethnicity, and gender. The authors focused on the NELS 1992 student survey in which there were over 15,000 respondents. In addition, the authors also analyzed the NELS Item Response Theory Exam scores from four subject areas: reading, math, science, and history. Hispanic female students displayed higher levels of civic engagement than Hispanic male students in every category except college graduation expectation $(54.09 \%$ female vs. $55.03 \%$ male $)$.

In regards to the Item Response Theory (IRT) exam scores, Hispanic male students outperformed Hispanic female students in every subject area except for Reading. One study that provided the demographic data described the Hispanic students that participated in the study as "Mexican American" or "Other Hispanic" (Davila \& Mora, 2007a, p. 5).

The results of the NAEP (2006) civics test for eighth graders display the civic knowledge deficiency male and female Hispanic students have in comparison with students from other races. Hispanic male students scored higher (130) in the NAEP eighth grade civics exam than Black male students (128) and American Indian/Alaska Native male students (122). However, White male students (160) and Asian/Pacific Islander male students (156) are surpassing Hispanic male students in civic knowledge.

Although Hispanic female students (133) performed better than Hispanic male students (130), Hispanic female students performed worse in comparison to White, Black, and Asian female students. Hispanic female students displayed a slightly higher civic knowledge score than American Indian/Alaska Native female students (132). White 
female students (161), Asian/Pacific Islander female students (153), and Black female students (137) outperformed Hispanic female students (133) in the eighth grade NAEP civics exam.

The results for Hispanic students in the $12^{\text {th }}$ grade NAEP civics exam (NAEP, 2006) virtually mirrored the results of Hispanic students in the eighth grade NAEP civics exam. Hispanic female students (135) scored higher than Hispanic male students (133). However, both Hispanic male and female students scored lower than students from their own gender with the exception of Black male students (128) and Black female students (133).

\section{Theoretical Framework for the Study}

This study is guided by the Octagon model of the IEA CivEd study. The National Research Coordinators of the IEA developed the theoretical model for the CivEd study. The model, known as the 'Octagon', "is a visualization of ways in which the everyday lives of young people in homes, with peers and at school serve as a 'nested' context for young people's thinking and action in the social and political environment" (TorneyPurta et al., 2001, p. 22). In other words, the model acknowledges factors other than school that influence students.

The model is based on the psychological theories of ecological development (Brofenbrenner, 1988) and situated cognition (Lave \& Wegner, 1991; Wenger, 1998). The model emphasizes the importance of citizens being engaged in the community as well as the significance of developing and practicing public discourse (Torney-Purta et al., 2001). The model displays all the factors that influence the lives of the individual 
student. The circle of the Octagon model displays the factors that have direct influence on the student.

Figure 1. Model for the IEA CivEd Study. This figure illustrates the everyday lives of students in the social and political environment (Torney-Purta et al., 2001).

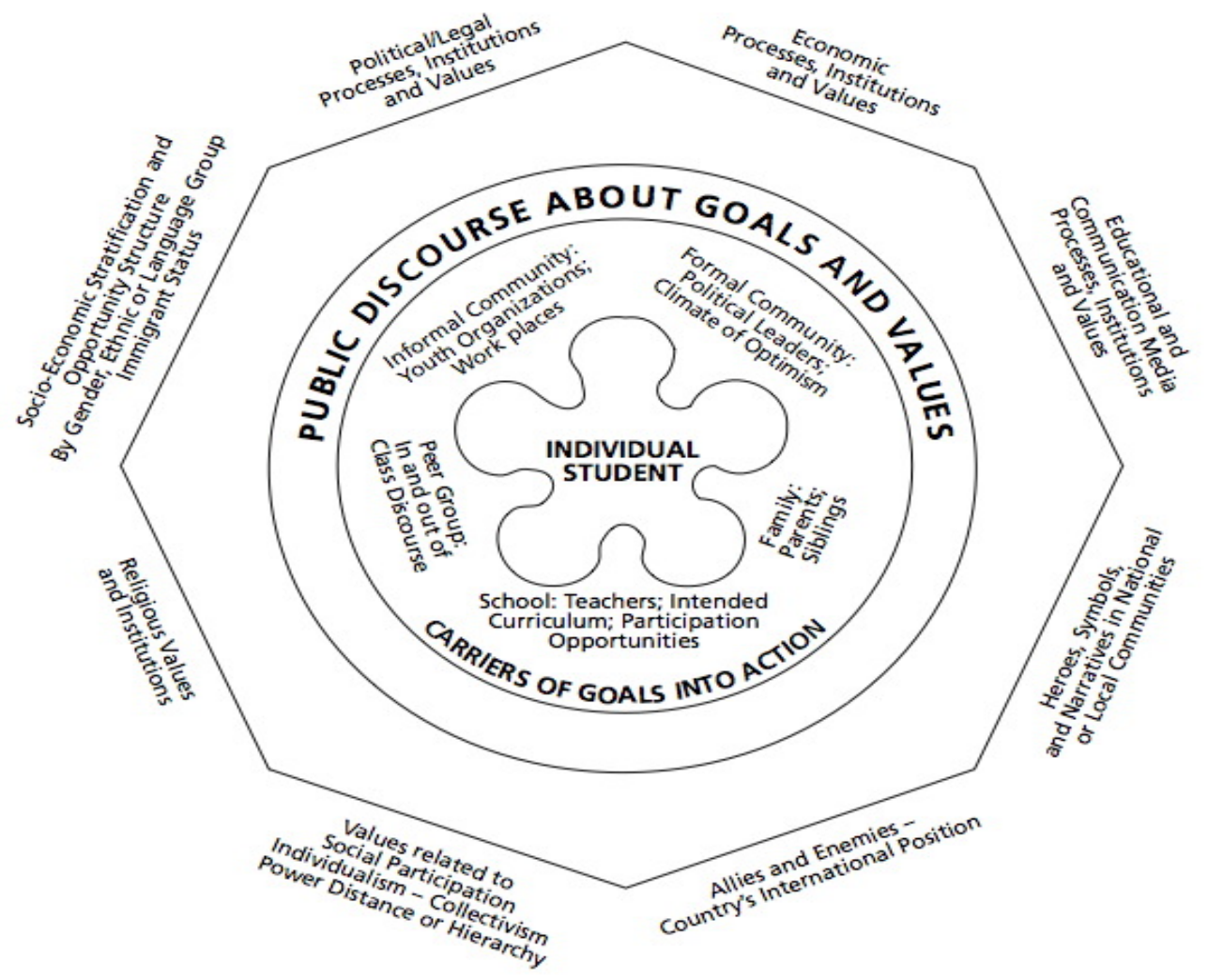

Torney-Purta et al. (2001) describe the circle of the Octagon model as the daily interactions the individual student goes through in their daily life:

The public discourse and practices of the society have an impact on the student through contacts with family (parents, siblings and sometimes extended family), school (teachers, implemented curriculum and participation opportunities, peer groups (both in and out of class), and neighbors (including people in out-ofschool youth organizations). (pp. 22-23)

The exterior of the Octagon details the societal factors that influence the individual student such as religion, politics, economics, and education. Furthermore, the exterior of 
the Octagon include the countries' international position, opportunity structure by gender, ethnic, or language group, as well as immigration status.

The Octagon model for the IEA CivEd study supports the idea that social studies (for the purpose of the current study, civics) is not the only facet of schooling that develops democratic understanding and participation (Hahn, 2001a). Hahn (2001a) states that "Civic education is a school-wide mission, with a variety of subjects, extracurricular activities, and the general school ethos contributing to preparing youth for life in a democracy" (p. 15). Nevertheless, schools provide the atmosphere in which the majority of the concepts of the Octagon model have an opportunity to interact (Banks, 2005; Parker, 2005). According to Banks (2005), "public schools have the two essential elements for helping young people grow into the social consciousness of puberty: a diverse student body and collective problems" (p. 655). Parker (2005) compares schools as village squares, cities, meeting places, and community centers. Parker (2005) believes that the schools teach students "tolerance, the respect, the sense of justice, and the knack for forging public policy with others whether one likes them or not" (p. 348).

The Octagon model for the IEA CivEd study served as the theoretical framework for two of the most comprehensive studies regarding the civic knowledge and engagement of students. The first study was completed in 1999. Over 90,000 14-year old students from 28 countries took part in the study (Torney-Purta et al., 2001). The second study was completed in 2000. Close to 50,000 upper secondary school students aged 16 to 19 years were involved in the study (Amadeo et al., 2002). The two studies tested students' civic knowledge, skills, and attitudes. The students were surveyed on their understanding of democracy and government; their attitudes related to trust in 
institutions, opportunities for immigrants and women, and political efficacy; and their expected participatory actions related to politics (civic engagement).

\section{Summary}

This chapter presented a review of selected literature on theoretical frameworks for civic education, civic education in the United States as well as the civic achievement gap of Hispanic students in the United States relevant to the purpose of this study. The subsections included brief discussions on the civic achievement gap of Hispanic students based on ancestry, the role of SES in the civic achievement gap of Hispanic students, and the role of gender in the civic achievement gap of Hispanic students. The theoretical framework of the study, the Octagon Model of the IEA CivEd Study was also presented. 


\section{CHAPTER III}

\section{METHODS}

The purpose of this study was to assess the civic knowledge, skills, and attitudes of Hispanic students in M-DCPS. Specifically, this research was designed to investigate the levels of civic knowledge, skills, and attitudes of Hispanic students based on ancestry (i.e., Cuban, Colombian, and Nicaraguan), SES, and gender.

This chapter describes the research design, setting, participants, and instrumentation that were used in the study. One survey instrument developed by the IEA: the International Study of Civic Education (CivEd) Student Questionnaire was used in this study. This instrument was chosen due to its careful development as well as its use in the largest and most rigorous study of adolescents' civic knowledge, skills, and attitudes to date (Amdaeo et al., 2002; Torney-Purta et al., 2001). This chapter also describes the validity and reliability of the IEA CivEd Student Questionnaire as well as the method for data analysis used in the study.

\section{Research Design}

The research design of the study is an ex post facto design. This study investigated the civic knowledge, skills, and attitudes of Hispanic students based on ancestry, gender, and socioeconomic status (SES). Data were analyzed using a series of three multiple analyses of variance (MANOVA). This strategy is superior to using a series of analysis of variance since it increases the statistical power of the hypotheses tested in the study and it allows for better control of Type I error (Weinfurt, 1995).

\section{Research Questions and Hypotheses}

This study addressed the following research questions and hypotheses: 
1. Is there a significant difference in the levels of civic knowledge, skills, and the civic attitudes of Hispanic students who are of different nationalities (i.e., comparing students who are of Cuban, Colombian, and Nicaraguan ancestry)?

H1a. There is no significant difference in the level of civic knowledge of Hispanic students who are of different nationalities (i.e., comparing students who are of Cuban, Colombian, and Nicaraguan ancestry).

H1b. There is no significant difference in the level of civic skills of Hispanic students who are of different nationalities (i.e., comparing students who are of Cuban, Colombian, and Nicaraguan ancestry).

H1c. There is no significant difference in the civic attitudes of Hispanic students who are of different nationalities (i.e., comparing students who are of Cuban, Colombian, and Nicaraguan ancestry).

2. Do middle to high SES students score higher in tests of civic knowledge, skills, and civic attitudes in comparison to students of low SES?

$\mathrm{H} 2 \mathrm{a}$. There is no significant difference on tests of civic knowledge of Hispanic students who pay full price for lunch compared to students who receive free/reduced lunch.

$\mathrm{H} 2 \mathrm{~b}$. There is no significant difference on tests of civic skills of Hispanic students who pay full price for lunch compared to students who receive free/reduced lunch.

$\mathrm{H} 2 \mathrm{c}$. There is no significant difference in civic attitudes of Hispanic students who pay full price for lunch who pay full price for lunch compared to students who receive free/reduced lunch. 
3. Is there a significant difference in the levels civic knowledge, skills, and civic attitudes of Hispanic male students and Hispanic female students?

H3a. There is no significant difference in the level of civic knowledge of Hispanic male students and Hispanic female students.

H3b. There is no significant difference in the level of civic skills of Hispanic male students and Hispanic female students.

H3c. There is no significant difference in civic attitudes of Hispanic male students and Hispanic female students.

The null hypotheses were tested at the .01 level of significance. The .01 level of significance was chosen because the Type I error (the probability of rejecting the null hypothesis when, in fact, the null hypothesis is true) is the least desirable error for this study.

\section{Setting}

The study was conducted at 10 middle schools that were purposefully selected. The researcher determined that purposeful sampling would be the most appropriate method to achieve a sample size of 350 students of Cuban, Nicaraguan, and Colombian ancestry. At the .01 level of significance testing for a moderate effect size, a sample of 350 participants yields a power of .99 (Cohen, 1988). The 10 purposefully selected middle schools have high enrollments of students with the aforementioned Hispanic origin. The researcher contacted the principals, Social Studies Department Chairpersons, and U.S. History teachers from the selected schools to get their permission to participate in the study and to explain the details as to how the study would be conducted. 
The researcher chose to assess students of Cuban, Nicaraguan, and Colombian ancestry because of their rich history in Miami-Dade County as well as their large population. In the 1980s, Miami-Dade County's Cuban, Nicaraguan, and Colombian populations increased dramatically due to the political turmoil in each respective country. In 1980 alone, over 125,000 Cubans arrived in the United States during the Mariel Boatlift. Colombians immigrated to Miami-Dade County due to the civil war between the Colombian government and the Revolutionary Armed Forces of Colombia (FARC) as well as the violence caused by the drug cartels. Nicaraguans fled their homeland due to the civil war between the Contras and the Sandinistas. As of 2005, Cubans, Nicaraguans, and Colombians made up the largest percentage of foreign-born Hispanics in MiamiDade County, Florida (45\%, 7\%, 7\%, respectively; Miami-Dade County Department of Planning and Zoning, Research Section, 2007). Furthermore, students of Cuban, Nicaraguan, and Colombian ancestry make up a large proportion of foreign-born Hispanic students in M-DCPS (27,715, 6,828, 2,499, respectively; M-DCPS, 2008). MDCPS is the fourth largest school district in the United States. During the 2010-2011 school year approximately 345,000 students are enrolled in M-DCPS. Approximately $62.5 \%$ of the students were Hispanic, $25.7 \%$ were Black non-Hispanic, 9.1\% were White non-Hispanic, and 2.7\% were American Indian, Asian, or Multiracial. In addition, 63.4\% of the students qualified for free/reduced lunch. Also during the 2010-2011 school year, the eighth grade population consisted of approximately 26,000 students, of whom 16,000 were Hispanic (M-DCPS, 2010).

Principals, Social Studies Department Chairpersons, and U.S. History teachers from the 10 middle schools that participated in the study from M-DCPS were asked via e- 
mail to take part in the study. Social studies teachers from the 10 middle schools who were currently teaching U.S. History in M-DCPS administered the instrument to their eighth grade U.S. History classes. The M-DCPS Division of Social Sciences assisted in sending e-mails to U.S. History teachers. Reminder e-mails were sent once a week for a period of 9 weeks. In addition, the researcher visited the selected schools and met with the principals, Social Studies Department Chairpersons, and U.S. History teachers. Once the students completed the IEA CivEd Student Questionnaire, the data were transferred to SPSS for analysis.

\section{Participants}

The purpose of this study was to assess the civic knowledge, skills, and attitudes of Hispanic middle school students in M-DCPS. M-DCPS is divided into five geographic regions. However, only four geographic regions were selected because one of the geographic regions did not contain an adequate population of students of Cuban, Colombian, and Nicaraguan ancestry. Each region contains 10 to 13 middle schools. Ten middle schools from the four geographic regions were selected for the study in order to determine the civic knowledge, skills, and attitudes of Hispanic students. Furthermore, two to three U.S. History classes from each of the participating middle schools participated in the study. Three hundred sixty one students participated in the study. The questionnaires of students that were not of Cuban, Colombian, and Nicaraguan ancestry were placed in a file cabinet in a secure location and not used in this study. The average age of an eighth grade student in M-DCPS is 14 years old. The grade and age of the IEA CivEd study was ninth grade and 14 years old, respectively. The U.S. History teachers 
administered a paper copy of the IEA CivEd Student Questionnaire at the selected MDCPS middle schools.

\section{Instrumentation}

The instrument was chosen because it measures the civic knowledge, skills, and attitudes of students. Furthermore, the instrument was also selected for the current study because of the rigorous steps it underwent to be developed for two of the most comprehensive studies on the civic knowledge, skills, and attitudes of secondary school students (Amdaeo et al., 2002; Schulz \& Sibberns, 2004; Torney-Purta et al., 2001). The publicly available version of the IEA CivEd student instrument (Torney-Purta et al., 2001) was used in this study. The IEA CivEd student instrument is divided into three parts. The first section consists of 16 multiple-choice civic knowledge and skills test questions with correct and incorrect answers. The second section is comprised of questions pertaining to the students' background. The third section is comprised of 30 items that focus on the students' attitude toward the government, immigrants, and women's political rights and the students' civic engagement and expected participatory actions relating to political activities.

The IEA administered the CivEd Student Questionnaire in 1999 to 90,000 14year-old students in 28 countries (Torney-Purta et al., 2001). In 2000, the IEA administered the CivEd Student Questionnaire to 50,000 upper secondary school students (16 to 19 years of age) in 16 countries (Amadeo et al., 2002). The 16 publicly available multiple-choice test questions developed by the IEA were used for the current study. Furthermore, 30 survey items that were scaled in the 1999 IEA CivEd study were used in the current study (Torney-Purta et al., 2001). 


\section{IEA CivEd Student Questionnaire: Test of Knowledge of Civic Content and Skills}

The International Steering Committee and the National Research Coordinators of the IEA CivEd study developed the IEA CivEd Student Questionnaire between 1996 and 1998. After several meetings, the National Research Coordinators and the International Steering Committee chose three domains of topics that 14-year-olds should understand:

Domain I: Democracy

What does democracy mean, and what are its associated institutions and practices? The three sub-domains were:

A) Democracy and its defining characteristics

B) Institutions and practices in democracy

C) Citizenship - rights and duties

Domain II: National Identity, Regional and International Relationships

How can the sense of national identity or national loyalty among young people be described, and how does it relate to their orientation to other countries and to regional and international organizations? The two sub-domains were:

A) National identity

B) International/regional relations

Domain III: Social Cohesion and Diversity

What do issues of social cohesion and diversity mean to young people, and how do they view discrimination? (Torney-Purta et al., 2001, p. 29).

Based on these domains, the national research coordinators defined two types of items to be included in the test of knowledge of civic content and skills:

Type 1 items: assessing knowledge of content. 
Type 2 items: assessing skills in interpretation of materials with civic or political content (including short text passages and cartoons; Torney-Purta et al., 2001, p. 29).

The original test consisted of 38 multiple-choice questions. The test has a Cronbach's alpha reliability coefficient of .85 . Each multiple-choice item consisted of four answer categories, one with the correct response and three with incorrect responses (distracters). The IEA CivEd Student Questionnaire has been used effectively in previous research studies regarding the civic knowledge of 14-year-old students (TorneyPurta et al., 2001) and older adolescents (Amadeo et al., 2002).

\section{IEA CivEd Student Questionnaire: Survey on Civic Attitude and Civic Engagement}

The National Research Coordinators developed a survey in which the focus was shifted from content knowledge and skills to items that assessed the students understanding of concepts such as democracy, civic attitudes, and civic engagement (Schulz \& Sibberns, 2004). The survey of the IEA CivEd study consisted of 162 questions in which the students answered using a four-point Likert scale that also included a "don't know" option. However, this study focused only on the students' civic attitude and civic engagement. Therefore, the survey used in the study consisted of 30 questions.

The survey portion of the IEA CivEd Student Questionnaire used in the current study contains two main types of questions. The first focuses on students' civic attitudes and feelings of trust in the government and the second asks questions regarding their past, current, and expected participatory actions relating to politics (civic engagement). The survey that was used for the current study was divided as follows (see appendix for specific items): 
1. Attitudes: Items that assess the students' attitudes towards trust in institutions (Section C, six questions), rights for women (Section E, six questions), immigrants (Section F, five questions), and the perception of teaching styles in class (Section I, six questions).

2. Actions (civic engagement): Items that assess the students' participation in school (Section G, four questions) and expected political participation in the future (Section $\mathrm{H}$, three questions).

\section{Content Validity of the IEA CivEd Student Questionnaire}

The IEA CivEd Student Questionnaire was administered in 1999 to 90,000 students in 28 countries. This instrument was developed to measure the civic knowledge (including two sub-domains: civic content knowledge and skills in interpreting political communication) of 14-year-old students. Rigorous quality control processes were instituted for the design of the instruments. The Test of Knowledge of Civic Content and Skills (henceforth referred to as "the test") went through a pre-pilot and pilot study in which 20 and 25 countries participated, respectively. Meetings between National Research Coordinators and Data Processing Personnel discussed the sampling, weighting of sampling, and data submission. The items were reviewed periodically by the IEA Technical Executive Group. The survey portion of the IEA CivEd Student Questionnaire ("the survey") went through a pilot study in which 25 countries participated. The National Research Coordinators developed the survey items based on the research literature on political theories, concepts of democracy, previous research on students' and adults' concepts of democracy, previous research on concepts of good citizenship, and 
previous research with adults on concepts of government including social and economic responsibility.

\section{Estimate of Reliability of the IEA CivEd Student Questionnaire}

The IEA CivEd Student Questionnaire Test of Civic Knowledge and Skills that was used in the current study consists of the 16 publicly released multiple-choice test questions with a Cronbach's alpha reliability coefficient of .76 (Torney-Purta et al., 2001). The survey portion of the instrument used in the study includes 30 items that were scaled in the 1999 IEA CivEd Study (Torney-Purta et al., 2001). The survey was divided into six sections. The table below details the Cronbach's alpha reliability for each of the scales.

Table 1

Cronbach's Alpha Reliability Coefficients for All Scales of the IEA CivEd Student

Questionnaire Survey (Torney-Purta, et al., 2001)

\begin{tabular}{lcc}
\hline Scale Name & Alpha & $\begin{array}{c}\text { Number of } \\
\text { Items in Scale }\end{array}$ \\
\hline $\begin{array}{l}\text { Section C: Trust in Government-related } \\
\text { Institutions (civic attitude) }\end{array}$ & .78 \\
$\begin{array}{l}\text { Section E: Support for Women's Rights } \\
\text { (civic attitude) }\end{array}$ & .79 & 6 \\
$\begin{array}{l}\text { Section F: Positive Attitudes toward Immigrants } \\
\text { (civic attitude) }\end{array}$ & .82 & 5 \\
$\begin{array}{l}\text { Section G: Confidence in Participation in } \\
\text { School (civic engagement attitudes) }\end{array}$ & .69 & 4 \\
$\begin{array}{l}\text { Section H: Expected Participation in Political } \\
\text { Activities (civic engagement attitudes) } \\
\text { Section I: Classroom Discussions and }\end{array}$ & .73 & 3 \\
Participation (civic attitude) & .76 & 6 \\
\hline
\end{tabular}

\section{Procedure for Survey Administration}

Approval to conduct the study was sought from the Institutional Review Board (IRB) of Florida International University (FIU) and the M-DCPS Office of Evaluation 
and Research. E-mail with an attachment of the M-DCPS Office of Evaluation and research approval letter was sent to the principals, Social Studies Department Chairpersons, and U.S. History teachers of the 10 middle schools explaining the significance of the study and asking them to assist in encouraging their students to participate in the study. Follow up e-mails were sent to remind the principals, Social Studies Department chairpersons, and U.S. History teachers about the study. Surveys and consent forms were brought to each of the participating middle schools by the researcher. The researcher met with the eighth grade U.S. History teachers to prepare and instruct them on how to administer the questionnaire to their respective students. The teachers administered the paper questionnaire to eighth grade U.S. History students. The teachers contacted the researcher when their students completed the questionnaire. The researcher collected the materials on the same day the questionnaires were completed.

\section{Analysis of Data}

Three multivariate analyses of variance (MANOVA) were used to test differences in the civic knowledge, skills, and attitudes of Hispanic students based on the following variables: ancestry, SES, and gender. The .01 level of significance was used since a Type I error is the least desirable error for this study. Post hoc comparisons were carried out when necessary. Since the study involved multiple comparisons, Bonferroni-type adjustments helped control for Type 1 error inflation (Newman, Fraas, \& Laux, 2000).

\section{Summary}

The purpose of this chapter was to present the methods and procedures used to assess the civic knowledge, skills, and attitudes of Hispanic eighth grade students in MDCPS. One instrument was used to collect the data for this study: the IEA CivEd Student 
Questionnaire. Ten middle schools were purposefully selected to participate in the study. Three multivariate analyses of variance (MANOVA) were used to test differences in the civic knowledge, skills, and attitudes of Hispanic students from M-DCPS based on ancestry, gender, and SES. 


\section{CHAPTER IV}

\section{RESULTS}

This chapter presents the results of the study. This study investigated the civic knowledge, skills, and the civic attitudes of eighth grade Hispanic students from MDCPS. It specifically attempted to investigate and determine if differences of civic knowledge, skills, and attitudes exist among Hispanic students based on ancestry (i.e., Cuban, Colombian, and Nicaraguan), SES, and gender. This chapter also describes the sample and tests of hypotheses used in the study.

\section{Description of the Sample}

Ten middle schools from M-DCPS participated in the study. Three hundred sixty one eighth grade Hispanic students participated in the study of whom 136 were boys and 225 were girls. Of the 361 Hispanic students, 253 students of Cuban ancestry, 57 students of Colombian ancestry, and 51 students of Nicaraguan ancestry participated in the study. Two hundred twenty eight received free or reduced lunch (low SES) and 133 paid for their lunch (middle to high SES). Descriptive statistics of the civic knowledge, skills, and attitudes of the students based on ancestry, SES, and gender are shown in Table 2.

This study was designed to investigate the levels of civic knowledge, skills, and attitudes of Hispanic students based on ancestry (i.e., Cuban, Colombian, and Nicaraguan), SES, and gender. The following research questions and the hypotheses that derive from each question and were addressed in the study are shown below. All hypotheses were tested at the $\alpha=.01$ level of significance. 
Table 2

Descriptive Statistics for the Sample $(N=361)$

\begin{tabular}{|c|c|c|c|c|c|c|c|}
\hline \multirow[b]{2}{*}{ Scale } & \multicolumn{3}{|c|}{ Ancestry } & \multicolumn{2}{|c|}{ SES } & \multicolumn{2}{|c|}{ Gender } \\
\hline & Cuban & Colombian & Nicaraguan & Low & Middle & Male & Female \\
\hline $\begin{array}{l}\text { Civic } \\
\text { Knowledge }\end{array}$ & $\begin{array}{c}6.35 \\
(1.93)\end{array}$ & $\begin{array}{c}6.74 \\
(1.68)\end{array}$ & $\begin{array}{c}6.08 \\
(1.78)\end{array}$ & $\begin{array}{c}6.13 \\
(1.85)\end{array}$ & $\begin{array}{c}6.78 \\
(1.86)\end{array}$ & $\begin{array}{c}6.27 \\
(1.91)\end{array}$ & $\begin{array}{c}6.43 \\
(1.86)\end{array}$ \\
\hline Civic Skills & $\begin{array}{c}5.25 \\
(1.98)\end{array}$ & $\begin{array}{c}5.42 \\
(1.82)\end{array}$ & $\begin{array}{c}5.31 \\
(1.87)\end{array}$ & $\begin{array}{c}5.12 \\
(2.02)\end{array}$ & $\begin{array}{c}5.56 \\
(1.75)\end{array}$ & $\begin{array}{c}4.89 \\
(2.14)\end{array}$ & $\begin{array}{c}5.52 \\
(1.77)\end{array}$ \\
\hline $\begin{array}{l}\text { Civic } \\
\text { Attitudes }\end{array}$ & & & & & & & \\
\hline $\begin{array}{r}\text { Trust in } \\
\text { Institutions }\end{array}$ & $\begin{array}{l}2.88 \\
(.62)\end{array}$ & $\begin{array}{l}2.74 \\
(.71)\end{array}$ & $\begin{array}{l}5.31 \\
(.68)\end{array}$ & $\begin{array}{l}2.81 \\
(.68)\end{array}$ & $\begin{array}{l}2.92 \\
(.56)\end{array}$ & $\begin{array}{l}2.86 \\
(.65)\end{array}$ & $\begin{array}{l}2.85 \\
(.64)\end{array}$ \\
\hline $\begin{array}{r}\text { Support of } \\
\text { Women's } \\
\text { Rights }\end{array}$ & $\begin{array}{l}3.50 \\
(.58)\end{array}$ & $\begin{array}{l}3.46 \\
(.64)\end{array}$ & $\begin{array}{l}3.46 \\
(.64)\end{array}$ & $\begin{array}{l}3.44 \\
(.65)\end{array}$ & $\begin{array}{l}3.57 \\
(.54)\end{array}$ & $\begin{array}{l}3.20 \\
(.74)\end{array}$ & $\begin{array}{l}3.67 \\
(.43)\end{array}$ \\
\hline $\begin{array}{r}\text { Positive } \\
\text { Attitudes } \\
\text { Toward } \\
\text { Immigrants }\end{array}$ & $\begin{array}{l}3.36 \\
(.53)\end{array}$ & $\begin{array}{l}3.43 \\
(.614)\end{array}$ & $\begin{array}{l}3.35 \\
(.52)\end{array}$ & $\begin{array}{l}3.38 \\
(.53)\end{array}$ & $\begin{array}{l}3.35 \\
(.56)\end{array}$ & $\begin{array}{l}3.30 \\
(.56)\end{array}$ & $\begin{array}{l}3.41 \\
(.52)\end{array}$ \\
\hline $\begin{array}{r}\text { Confidence } \\
\text { in }\end{array}$ & & & & & & & \\
\hline $\begin{array}{r}\text { Participation } \\
\text { in School }\end{array}$ & $\begin{array}{l}3.23 \\
(.67)\end{array}$ & $\begin{array}{l}3.25 \\
(.74)\end{array}$ & $\begin{array}{l}3.15 \\
(.55)\end{array}$ & $\begin{array}{l}3.23 \\
(.64)\end{array}$ & $\begin{array}{l}3.22 \\
(.70)\end{array}$ & $\begin{array}{l}3.07 \\
(.74)\end{array}$ & $\begin{array}{l}3.32 \\
(.60)\end{array}$ \\
\hline $\begin{array}{r}\text { Expected } \\
\text { Participation } \\
\text { in Political } \\
\text { Activities }\end{array}$ & $\begin{array}{l}2.26 \\
(.82)\end{array}$ & $\begin{array}{l}2.25 \\
(.67)\end{array}$ & $\begin{array}{l}2.17 \\
(.69)\end{array}$ & $\begin{array}{l}2.19 \\
(.74)\end{array}$ & $\begin{array}{l}2.33 \\
(.84)\end{array}$ & $\begin{array}{l}2.20 \\
(.89)\end{array}$ & $\begin{array}{l}2.26 \\
(.71)\end{array}$ \\
\hline $\begin{array}{l}\text { Classroom } \\
\text { Discussions } \\
\text { and } \\
\text { Participation }\end{array}$ & $\begin{array}{l}3.25 \\
(.62)\end{array}$ & $\begin{array}{l}3.38 \\
(.59)\end{array}$ & $\begin{array}{l}3.19 \\
(.52)\end{array}$ & $\begin{array}{l}3.19 \\
(.60)\end{array}$ & $\begin{array}{l}3.39 \\
(.58)\end{array}$ & $\begin{array}{l}3.17 \\
(.61)\end{array}$ & $\begin{array}{l}3.32 \\
(.59)\end{array}$ \\
\hline
\end{tabular}

Note: Numbers outside parentheses are means. Numbers inside parentheses are standard deviations.

The Civic Attitudes scale is composed of six subscales. 


\section{Research Questions and Hypotheses}

1. Is there a significant difference in the levels of civic knowledge, skills, and the civic attitudes of Hispanic students who are of different nationalities (i.e., comparing students who are of Cuban, Colombian, and Nicaraguan ancestry)?

H1a. There is no significant difference in the level of civic knowledge of Hispanic students who are of different nationalities (i.e., comparing students who are of Cuban, Colombian, and Nicaraguan ancestry).

H1b. There is no significant difference in the level of civic skills of Hispanic students who are of different nationalities (i.e., comparing students who are of Cuban, Colombian, and Nicaraguan ancestry).

H1c. There is no significant difference in the civic attitudes of Hispanic students who are of different nationalities (i.e., comparing students who are of Cuban, Colombian, and Nicaraguan ancestry).

2. Do middle to high SES students score higher in tests of civic knowledge, skills, and civic attitudes in comparison to students of low SES?

$\mathrm{H} 2 \mathrm{a}$. There is no significant difference on tests of civic knowledge of Hispanic students who pay full price for lunch compared to students who receive free/reduced lunch.

$\mathrm{H} 2 \mathrm{~b}$. There is no significant difference on tests of civic skills of Hispanic students who pay full price for lunch compared to students who receive free/reduced lunch.

$\mathrm{H} 2 \mathrm{c}$. There is no significant difference in civic attitudes of Hispanic students who pay full price for lunch who pay full price for lunch 
compared to students who receive free/reduced lunch.

3. Is there a significant difference in the levels civic knowledge, skills, and civic attitudes of Hispanic male students and Hispanic female students?

H3a. There is no significant difference in the level of civic knowledge of Hispanic male students and Hispanic female students.

H3b. There is no significant difference in the level of civic skills of Hispanic male students and Hispanic female students.

H3c. There is no significant difference in civic attitudes of Hispanic male students and Hispanic female students.

\section{Tests of Hypotheses}

Three hypotheses were tested at the .01 level of significance by using a series of MANOVA procedures. The first hypothesis was tested to see if a significant difference exists in the civic knowledge, skills, and attitudes of Hispanic students based on ancestry (i.e., Cuban, Colombian, and Nicaraguan). The second hypothesis was tested to see if a significant difference exists in the civic knowledge, skills, and attitudes of Hispanic students based on SES. The third hypothesis was tested to see if a significant difference exists in the civic knowledge, skills, and attitudes of Hispanic students based on gender.

\section{Hypothesis 1}

In order to test the first hypothesis, a MANOVA was employed using ancestry as the independent variable and a canonical function composed of civic knowledge, skills, and attitudes. The results indicated that there was no significant difference in the canonical function based on ancestry $(\Lambda=.966, F(16,702)=.762, p=.729)$. 


\section{Hypothesis 2}

In order to test the second hypothesis, a MANOVA was employed using SES as the independent variable and a canonical function composed of civic knowledge, skills, and attitudes. The results indicated that there was a significant difference in the canonical function based on $\operatorname{SES}(\Lambda=.935 F(8,352)=3.053, p=.002)$. Further examination indicated that the variables civic knowledge $\mathrm{F}(1,359)=10.297, p=.001$ and the civic attitude items about classroom discussions and participation $\mathrm{F}(1,359)=$ $9.022, p=.003$ were significantly different between SES groups. It was found that the mean score of civic knowledge for students who did not qualify for free lunch $(M=6.78)$ was higher than that of students who were eligible to receive free or reduced lunch $(M=6.13)$. Furthermore, the mean score of the civic attitude for classroom discussions and participation for students that do not qualify for free lunch $(M=3.39)$ was higher than students that are eligible for free or reduced lunch $(M=3.19)$.

\section{Hypothesis 3}

In order to test the third hypothesis, a MANOVA was employed using gender as the independent variable and a canonical function composed of civic knowledge, skills, and attitudes. The results indicated that there was a significant difference in the canonical function based on gender $(\Lambda=.829 F(8,352)=9.086, p<.001)$. Further examination indicated that the variables civic skills $\mathrm{F}(1,359)=10.879, p<.001$ and the civic attitude of support for women's rights and their roles in politics $F(1,359)=42.528$ $p=<.001$ were significantly different between gender groups. It was found that the mean of the civic skills score for girls $(M=5.52)$ was higher than that of boys $(M=4.89)$. 
Furthermore, girls displayed a higher mean score $(M=3.67)$ compared to boys $(M=3.20)$ on the civic attitude of support for women's rights and their role in politics.

\section{Summary}

The results indicated that there was no significant difference in the civic knowledge, skills, and attitudes of Hispanic students based on ancestry. However, there was a significant difference in the civic knowledge and the civic attitude for classroom discussions and participation based on SES. The data analysis found that the civic knowledge of Hispanic students who pay for lunch was higher than Hispanic students who receive free or reduced lunch. Furthermore, Hispanic students who pay for lunch displayed higher mean score for the civic attitude of classroom discussions and participation than Hispanic students that receive free or reduced lunch.

The results also indicated that there was a significant difference in the civic skills and the civic attitude of support for women's rights and their role in politics between gender groups. It was found that the mean score of civic skills for Hispanic female students was higher than that of Hispanic male students. Furthermore, the mean score of civic attitude of support for women's rights and their role in politics for Hispanic female students was higher than that of Hispanic male students. 


\section{CHAPTER V}

\section{DISCUSSION}

This chapter presents a summary of the study, a discussion of the findings, conclusions based on study results, and implications of the findings and possible directions for future research.

\section{Overview of the Study}

The purpose of the study was to assess the civic knowledge, skills, and attitudes of Hispanic eighth grade students in M-DCPS. Three hundred sixty one Hispanic students of Cuban (253), Colombian (57), and Nicaraguan (51) ancestry from 10 purposefully selected middle schools participated in the study. Two hundred twenty eight received free or reduced lunch (low SES) and 133 paid for their lunch (middle to high SES) and 136 were boys and 225 were girls. The IEA CivEd Student Questionnaire was used to collect the data for this study. The instrument assessed the students' civic knowledge, skills, and attitudes. The IEA CivEd student instrument is divided into 3 parts. The first section consists of 16 multiple-choice civic knowledge and skills test questions with correct and incorrect answers. The second section is comprised of questions pertaining to the students' background. The third section was comprised of 30 questions that measured the students' civic attitudes. The 30 questions focused on the students trust in government-related institutions, support for women's rights, positive attitudes toward immigrants, confidence in participation in school, expected participation in political activities, and classroom discussions and participation. Three multivariate analyses of variance (MANOVA) were used to test differences in the civic knowledge, 
skills, and attitudes of Hispanic students from M-DCPS based on ancestry, SES, and gender.

\section{Summary of the Findings}

In this section, the findings of the study are presented in relation to the three research questions. The findings are discussed in the following section.

\section{Research Question \#1}

Is there a significant difference in the civic knowledge, skills, and attitudes of Hispanic students who are of different nationalities (i.e., comparing students that are of Cuban, Colombian, and Nicaraguan ancestry)? No significant difference was found in the civic knowledge, skills, and attitudes of Hispanic eighth grade students that are of Cuban, Colombian, and Nicaraguan ancestry.

Research Question \#2

Do middle to high SES students score higher in tests of civic knowledge, skills, and attitudes in comparison to students of low SES? There was no significant difference in the civic skills and on five of the civic attitude scales for students who are on free/reduced lunch compared to those who pay for their lunch. However, there was a significant difference in the civic knowledge and the civic attitude of classroom discussions and participation based on SES. The civic knowledge of Hispanic students who pay for lunch was higher than for Hispanic students who receive free or reduced lunch. Furthermore, Hispanic students who pay for lunch displayed a higher mean score for civic attitude of classroom discussions and participation than Hispanic students that receive free or reduced lunch. 


\section{Research Question \#3}

Is there a significant difference in the civic knowledge, skills, and attitudes of Hispanic male students and Hispanic female students? There was no significant difference in the civic knowledge and on five of the civic attitude scales between boys and girls. However, there was a significant difference in the civic skills and the civic attitude of support for women's rights and their role in politics between boys and girls. Hispanic girls displayed a higher mean score in civic skills than Hispanic boys. Furthermore, the mean score of civic attitude of support for women's rights for Hispanic girls was higher than that of Hispanic boys.

\section{Discussion of the Findings}

\section{Role of Ancestry in the Civic Achievement Gap of Hispanic Students}

Research regarding the civic achievement gap differences among Hispanic ancestry is limited. The limited research that does exist tends to focus only on one group such as Mexican-American elementary school children (Griggs \& Dunn, 1996) or researchers

group all Hispanics into one group (Wrinkle, Stewart, Polinard, Meier, \& Arvizu, 1996). The current study contributed to the existing research on the civic achievement gap among Hispanic students. No significance difference in the civic knowledge, skills, and attitudes amongst the three largest Hispanic groups (i.e., Cuban, Colombian, and Nicaraguan) in M-DCPS was found based on ancestry.

The fact that the current study found no significant difference in the civic knowledge, skills, and attitudes amongst students of Cuban, Colombian, and Nicaraguan ancestry is important. The theoretical model of the current study, the Octagon model, states that, "The public discourse and practices of the society have an impact on the 
student through contacts" (Torney-Purta et al., 2001, p. 20). The student's family (parents, siblings, and extended family) is one of these important "contacts" described in the Octagon model. The students' parents and siblings "serve as a 'nested' context for young people's thinking and action in the social and political environment" (TorneyPurta et al., 2001, p. 20). Furthermore, the exterior of the Octagon model displays societal factors that also have an impact on the student. One of these societal factors take into account the "opportunity structure based on immigrant status". This theoretical framework can lead to the assumption that a particular group (for the purpose of this study, Cubans) living for a longer period of time in a country in comparison to other groups (for the purpose of this study, Colombians and Nicaraguans) would display higher scores of civic knowledge, skills, and attitudes. Conversely, the findings of the current study contradict that assumption. Cubans have been immigrating to the United States decades before Nicaraguans and Colombians. However, this study found no significant difference in the civic knowledge, skills, and attitudes of Hispanic students based on ancestry. Therefore, it can be deduced from the findings of this study that the number of years or generations individuals of a particular Hispanic ancestry has been living in the United States does not correlate to having more or less civic knowledge, better or worse civic skills, and more positive or negative civic attitudes.

In May 2010, NAEP released the Civics 2010 assessment scores. The NAEP 2010 Civics scores highlighted positive news regarding the civic achievement gap of Hispanic students. The scores demonstrated that the civic achievement gap between Hispanic students and White students narrowed in grades eight and 12. According to NAEP, "civics scores for Hispanic students were higher in 2010 than in 2006 at grade 8, and 
higher than in 1998 at all three grades" (NAEP, 2011, p. 3). The Hispanic student population was the racial/ethnic group that demonstrated the most significant gains in all three grades that were assessed (fourth, eighth, and $12^{\text {th }}$ ). NAEP did not offer explanations of how or why the scores of Hispanic students increased. Moreover, NAEP has continued to not state the ancestry of the Hispanic students who participated in the study.

\section{Role of SES in the Civic Achievement Gap of Hispanic Students}

The findings of the current study are consistent with the literature on the civic knowledge of students based on SES. The IEA CivEd study found that students of higher SES in the United States performed better in the civic knowledge portion of the instrument (Baldi et al., 2001). Hutchens and Eveland (2009) found that schools with higher numbers of economically disadvantaged students displayed lower mean scores on factual knowledge. The current study is also consistent with the results of the NAEP (2006) civics test. Eighth grade Hispanic students who paid for their lunch averaged 142 in the civics exam whereas Hispanic students on free/reduced lunch averaged 126.

The findings of the current study regarding the difference in civic skills between students of middle to high SES and low SES goes against the literature. The IEA CivEd study found that students of middle to high SES displayed higher civic skills than students of low SES (Torney-Purta et al., 2001). The current study found no significant difference in the civic skills of students who were on free/reduced lunch and those who had to pay for their lunch.

The economic downturn known as the Great Recession could be a reason that there was no significant difference in the civic skills and in five of the civic attitudes 
scales based on SES. Miami-Dade County's unemployment rate in April 2007 was 4\%. As of March 2011, the unemployment rate was 12\% (Federal Reserve Bank of St. Louis, 2011). With thousands of residents of Miami-Dade County unemployed, many students who previously paid for their lunch now qualified for free/reduced lunch. Therefore, it is plausible that this result could have been different if this study took place before the recession began in late 2007.

The study also found that students of low SES background did not feel that their social studies classroom provided an open climate for classroom discussions participation in comparison to students of middle to high SES. This finding is consistent with research that dates all the way back to the early 1970s. Verba and Nie (1972) in their research assert that SES is related to political participation. According to the authors, social status determines civic attitudes among people, in turn influencing their participation. They posit that three things are needed in order for citizens to be civically active: time, skills, and perhaps the most important item, money. Brady, Verba, and Schlozman (1995) in their research also assert the importance of time, money and civic skills in determining levels of political participation.

Furthermore, according to the Octagon model, the schools are the most accessible means for the individual student to participate in civic related activities. However, the current study found that students of low SES believe that their social studies classes are not conducive to in allowing them to freely express their opinions (civic attitude of classroom discussions and participation). The Octagon model highlights the student's everyday interaction, which includes their schools and peers. According to the Octagon model, these "communities of discourse and practice provide the situation in which 
young people develop progressively more complex concepts and ways of behaving" (Torney-Purta et al., 2001, p. 20). Furthermore, Torney-Purta et al. (2001) believe that the peers of a student play an important role because "reactions of peers to ideas are essential parts of the context for civic development" (p. 22). Therefore, according to the Octagon model and Torney-Purta et al., (2001) research, the students of the current study that are of low SES are in schools/classrooms that may be hindering their civic development.

The American Political Science Association's Task Force on Inequality and American Democracy (2004) summarized the advantages of being of higher SES in comparison to being of low SES best:

The privileged (those with more income) participate more than others and are increasingly well organized to press their demands on government. Public officials, in turn, are much more responsive to the privileged than to average citizens and the least affluent. Citizens with low or moderate incomes speak with a whisper that is lost on the ears of inattentive government, while the advantaged roar with the clarity and consistency that policymakers readily heed. (p.1)

According to the Octagon model, schools are an important factor in the development of the civic knowledge, skills, and attitudes of students. Hahn (2001a) states that "Civic education is a school-wide mission, with a variety of subjects, extracurricular activities, and the general school ethos contributing to preparing youth for life in a democracy" (p. 15). The importance of schools in the development of civics attitudes of adolescents of varying SES cannot be overstated. Schools are the place where students spend the "largest amount of time from age 6 until 17, and [where] teachers are uniquely positioned to influence civic knowledge, attitudes, and behaviors across socio-economic groups" (Torney-Purta, 2002, p. 203). Schools are able to develop public citizens who can better their community (Parker, 2005). Furthermore, schools can 
deter idiocy (Parker, 2005), which in turn, leads to enlightened and engaged citizens (Parker, 2006).

The NAEP 2010 Civics scores regarding the civic achievement gap between Hispanic students based on SES showed mixed results. The scores of Hispanic students based on SES were higher from the 2006 NAEP Civics exam. Eighth grade Hispanic students who were eligible for the National School Lunch Program (low SES) scored 130 in 2010, up from 126 in 2006. Eighth grade Hispanic students that were not eligible for the National School Lunch Program (middle to high SES) scored 150 in 2010, up from 141 in 2006. Twelfth grade Hispanic students that were eligible for the National School Lunch Program (low SES) scored 130 in 2010, up from 128 in 2006. Twelfth grade Hispanic students that were not eligible for the National School Lunch Program (middle to high SES) scored 146 in 2010, up from 139 in 2006. Although the civics scores of Hispanic students of varying SES increased, the civic achievement gap amongst students of low SES and middle to high SES persists.

\section{Role of Gender in the Civic Achievement Gap of Hispanic Students}

Research regarding the civic achievement gap differences between Hispanic male and female students is limited (Montoya, 1996). Therefore, based on a review of the literature on the civic knowledge of students based on gender, the findings of the current study are consistent with previous research. In the IEA CivEd study no significant difference was found in the civic knowledge of boys and girls in the United States (Torney-Purta et al., 2001).

Furthermore, the finding of the current study concerning the gender differences in civic skills is consistent with the literature in which girls display higher civic skills than 
boys. The IEA CivEd study in the United States found a significant difference in the civic skills of students based on gender. Regardless of the race or ethnicity of the student, girls displayed higher civic skills than boys on questions required reading and interpreting text materials (Baldi et al., 2001). Neimi and Junn (1998) in their research found that girls scored higher than boys on questions that required students to read and interpret text materials. The current study found that eighth grade Hispanic girls performed better in interpreting civic related materials (e.g. political cartoons, political leaflets, and distinguishing between fact and opinion) than eighth grade Hispanic boys. The results of this study concerning the civic attitude of support for women's rights is consistent with the review of the literature in which female students display higher levels of support for women's rights than male students (Hahn, 1998; Torney, Oppenheim, \& Farnen, 1975). The majority of the research that exists does not state if the participants are Hispanic. Nevertheless, the IEA CivEd study found that female students are more likely than male students to support women's political rights.

Furthermore, the same study found that the United States was one of nine countries that have larger gender differences (Torney-Purta et al., 2001). The current study is also consistent with Montoya's (1996) research on Latino gender differences. Her research stated that Hispanic women are more supportive than Hispanic men of women's social and political roles rights.

The IEA CivEd study found that countries with an unemployment rate of higher than $10 \%$ of the labor force displayed less positive attitudes towards women's rights (Torney-Purta et al., 2001). The researchers of the IEA CivEd study stated that the high unemployment rate may have influenced the students' scores. The unemployment rate of 
Miami-Dade County was at $12 \%$ when the current study took place. As a result, it is possible that the high unemployment rate may have influenced the Hispanic male students' support of women's rights.

According to the Octagon model, the teachers and the schools intended curricula play an important role in the individual student's understanding of civic attitudes such as support of women's rights and their playing an active role in politics. The schools, teachers, and the intended curriculum perhaps are not effectively teaching women's rights to boys. Furthermore, according to the Octagon model, the individual student's family, parents, and siblings also play a key role in shaping the students civic attitudes.

Moreover, the current study found no significant difference between boys and girls on the civic attitude scale of confidence in participation in school, is consistent with Hahn's (1998) research. However, the findings contradict those of the IEA CivEd study in which girls displayed higher confidence in the effectiveness of school participation (Torney-Purta et al., 2001).

The current study also found no significant difference between boys and girls concerning the civic attitude of "Positive Attitudes Toward Immigrants". This finding is not consistent with the IEA CivEd study in which female students demonstrated stronger positive attitudes toward immigrants' rights in comparison to male students. A possible explanation for this inconsistency is the fact the students who participated in the current study are first or second generation Hispanic Americans. Furthermore, M-DCPS is a multicultural school system that offers students the unique opportunity to interact with students of varying backgrounds and immigrant statuses. As of 2007, 21.3\% $(74,260)$ of 
the student population in M-DCPS was foreign-born representing 177 nations and territories (M-DCPS, 2008, p. 30).

The NAEP 2010 Civics scores regarding the civic achievement differences between Hispanic male and female students continue to demonstrate that girls in the eighth grade display higher civic achievement scores than boys (137 and 134, respectively). However, $12^{\text {th }}$ grade Hispanic female students achieved a lower score than $12^{\text {th }}$ grade Hispanic students (135 and 136, respectively). Further analysis demonstrates that Hispanic male and female students in the eighth and $12^{\text {th }}$ grade achieved a higher score in 2010 in comparison to 2006. Eighth grade female Hispanic students scored 137 in 2010, up from 132 in 2006. Eighth grade male Hispanic students scored 134 in 2010, up from 128 in 2006. Twelfth grade female Hispanic students scored 135 in 2010, up from 134 in 2006. Twelfth grade male Hispanic students scored 136 in 2010, up from 132 in 2006.

\section{Conclusions}

It was concluded that Cuban, Colombian, or Nicaraguan participants did not demonstrate differences in civic attitudes and levels of civic knowledge and skills that eighth grade students possessed. In addition, differences continue to exist between males and females regarding women's rights and their roles in politics. Moreover, SES continues to be a key factor in the acquisition of civic knowledge, regardless of ethnicity. It was also concluded that there is a civic achievement gap among Hispanic eighth grade students based on SES and gender.

\section{Implications}

The literature review revealed that there is a lack of research concerning the civic knowledge, skills, and attitudes of Hispanic students in the United States. This study 
stresses the need to further analyze more comprehensively and specifically the civic achievement gap of minority students.

One important implication of this study is in regard to the role of SES in the civic achievement of Hispanic students. The study found that SES is a determining key factor in the civic knowledge and attitudes of students. This variable could be more of a determining factor than the teacher's and the school's intended curriculum. The literature illustrates that regardless of race or ethnicity, SES plays an important role in the civic achievement level of the individual student (Baldi et al., 2001; Foster-Bey, 2008; Hutchens \& Eveland; 2009; Kahne, 2009; Kahne \& Middaugh; 2008; Verba \& Nie, 1972).

\section{Recommendations}

Based on the findings of this study and the conclusions reached, the following recommendations are offered:

1. Based on the literature review and the current research findings, school districts, administrators, and teachers need to be cognizant that regardless of ethnicity, the student's SES is correlated with their level of civic knowledge, skills, and attitudes. Therefore, schools should design and implement school activities in which all students, regardless of SES, are provided equal opportunity to participate. Many clubs/organizations require a membership or club fee to join. As a result, students of low SES are financially restricted in joining certain clubs/organizations. Therefore, school districts, schools, and clubs/organizations should put aside funding for students of low SES to join clubs/organizations. 
2. Based on the literature review and the current research findings on the importance of SES as determining factor in the acquisition of civic knowledge, skills and civic attitudes, it is recommend that the Octagon model places the socioeconomic stratification in the inner circle of the model next to the individual student rather than on the outside of the octagon.

\section{Future Research}

Researchers should focus on studying the civic achievement gap that exists among minority youth, in particular Hispanic adolescents. The limited quantity of literature that exists on the civic achievement gap of Hispanic students does not reflect the population growth of Hispanics of the last three decades (Torney-Purta et al., 2006). From 2000 to 2010, the Hispanic population accounted for 56\% of the nation's growth (Passel, Cohn, \& Lopez, 2011).

The 2010 U.S. Census has illustrated that Hispanics are moving to states that Hispanics traditionally did not immigrate to. The states with the largest percentages in Hispanic population growth were Alabama, Arkansas, Kentucky, Mississippi, North Carolina, South Carolina, and Tennessee. The Hispanic population also more than doubled in Maryland and South Dakota (Passel, Cohn, \& Lopez, 2011). Four states, Georgia, South Carolina, Florida, and Texas, gained seats in the Electoral College due to the growth of the Hispanic population in the southern United States $(1,1,2$, and 4 , respectively). As a result of all these changes, school districts around the country should conduct their own research regarding the civic knowledge, skills, and attitudes of their respective students. The findings of such a study can determine if a course of action is needed to address any civic achievement gaps. Furthermore, since the current study only 
focused on Hispanic students and was conducted in areas of Miami-Dade County in which they were they majority, future research should be conducted in M-DCPS to assess the civic knowledge, skills, and attitudes of students from other racial and ethnic backgrounds.

The current study only used one determinant regarding the SES of the student, which was if the student qualified for free or reduced lunch. Future research should also include the students' academic aspirations and the parents' level of education. However, future research should take precaution in including the number of books in the home as a determinant of the level of the student's SES. The increase use of computers, e-readers (e.g., Nook or Kindle), and tablet computers (e.g., iPad) as a means of reading books should be taken into account. Perhaps it would be more appropriate to ask the student if their family owns a computer, e-reader, or tablet computer rather than asking the number of books in the household.

The current study found that boys displayed a lower mean score of the civic attitude of support for women's rights in comparison to girls. Therefore, future research should be conducted to analyze the justification boys have in not placing women as equals when it comes to having rights and being involved in politics. Eighth grade boys grow up to be adult males with the ability to vote on major issues, which can include an important matter concerning women. As a result, research should be conducted to address and remedy this critical concern.

Civic research should focus on the students' use of the Internet and social media such as Facebook (which has over 700 million users) in relation to the students' civic knowledge, skills, and attitudes rather than watching news programs on television. The 
IEA CivEd (Torney-Purta et al., 2001) found that watching news programs on television is a positive predictor of civic knowledge in about half of the countries that participated in the study. In addition, the IEA CivEd study also found that television was the primary source for students to obtain information about politics (Baldi et al., 2001). However, 10 years later, a study by the Pew Research Center's Project for Excellence in Journalism found that Facebook is "emerging as a powerful news referring source." (Olmstead, Amy, \& Rosenstiel, 2011, para. 10).

Moreover, data released in June 2011 by the U.S. Department of Education bring to light that the achievement gap between Hispanic students and White students continues to be the same as it was in the early 1990s. Hispanic students continue to be two grade levels behind White students (Armario, 2011). According to Secretary of Education Arne Duncan, "Hispanic students are the largest minority group in our nation's schools. But they face grave educational challenges that are hindering their ability to pursue the American dream" (Armario, 2011, para. 3).

\section{Summary}

This study has contributed to the limited literature that exists concerning the civic knowledge, skills, and attitudes of Hispanic students. The demographic landscape of the United States has changed in the last two decades due to the growth of the Hispanic population yet the literature has not increased at the same pace.

Although this study focused on Hispanic students, it has provided some understanding of the extent to which SES is a key variable in the civic achievement of students. Further investigation of this issue can determine in greater scope and depth how policy makers, curriculum specialists, schools, and teachers can address and narrow 
the civic achievement gap of students of low SES and minority students. The researcher hopes that this study will provide other researchers with the framework needed to further analyze and study the civic knowledge, skills, and attitudes of Hispanic students in the United States in order to end the civic achievement gap which will lead to a citizenry comprised of competent and responsible citizens. 


\section{REFERENCES}

Abowitz, K., \& Harnish, J. (2006). Contemporary discourses of citizenship. Review of Educational Research. 76, 653-690.

Akos, P., \& Galassi, J. P. (2004). Gender and race as variables in psychosocial adjustment to middle and high school. The Journal of Educational Research, 98(2), 102-108.

Amadeo, J. A., Torney-Purta, J., Lehmann, R. H., Husfeldt V. \& Nikolova, R. (2002). Civic knowledge and engagement among upper secondary students. Citizenship and education in sixteen countries. Amsterdam, Netherlands: International Association for the Evaluation of Educational Achievement.

American Political Science Association, Task Force on Inequality and American Democracy (2004). American democracy in an age of rising inequality Retrieved from http://www.apsanet.org/imgtest/taskforcereport.pdf

Armario, C. (2011, June 23). Hispanic, white achievement gap as wide as in 90s. Retrieved from http://abcnews.go.com/US/wireStory?id=13915594

Baldi, S., Perie, M., Skidmore, D., Greenberg, E., Hahn, C., \& Nelson, D. (2001). What democracy means to ninth-graders: U.S. results from the international IEA Civic Education Study. ( NCES 2001-096). Washington, DC: U.S. Government Printing Office: U.S. Dept. of Education, National Center for Educational Statistics.

Banks, J. (2008) Citizenship education and diversity: Implications for teacher education in Peters, M. A. et.al. (Eds.), Global Citizenship Education: Philosophy, Theory and Pedagogy. P.318.

Brady, Henry E., Verba, Sidney and Schlozman, Kay Lehman. 1995. "Beyond SES: A Resource Model of Political Participation.” American Political Science Review, 89 pp. 271-294.

Braungart, R. G., \& Braungart, M. M. (1998). Citizenship and citizenship education in the United States in the 1990s. In O. Ichilov (Ed.), Citizenship and citizenship education in a changing world (267-273). London, UK: The Woburn Press.

Bronfenbrenner, U. (1988). Interacting systems in human development. In N. Bolger, C. Caspi, G. Downey, \& M. Moorehouse (Eds), Persons in context: Developmental processes (pp. 25-50). Cambridge, UK: Cambridge University Press.

Cammarota, J. (2004). The gendered and racialized pathways of Latina and Latino youth: Different struggles, different resistances in the urban context. Anthropology \&Education Quarterly, 34, 53-74. 
Carnegie Corporation of New York and CIRCLE. (2003). The Civic Mission of Schools. New York, NY.

Center for Civic Education, (1994). National standards for civics and government. Retrieved from http://www.civiced.org/index.php?page=stds preface

Cohen, J. (1998). Statistical power analysis for the behavioral sciences. (2 ed.). Hillside: Lawrence Earl Baum Associates.

Davila, A., \& Mora, M.T. (2007 a). Do gender and ethnicity affect civic engagement and academic progress?: Part II of an assessment of civic engagement and academic progress. The Center for Information \& Research on Civic Learning \& Engagement Working Paper, 53, 1-25.

Davila, A., \& Mora, M.T. (2007 b). Do gender and ethnicity affect civic engagement and academic progress?: Part II of an assessment of civic engagement and academic progress. The Center for Information \& Research on Civic Learning \& Engagement Working Paper, 53, 1-25.

Foster-Bey, J. (2008). Do race, ethnicity, citizenship and socio-economic status determine civic-engagement?. The Center for Information \& Research on Civic Learning \& Engagement Working Paper, 62.

Fry, R., \& Gonzales, F. (2008). One-in-five and growing fast: A profile of Hispanic public school students. Pew Hispanic Center.

Goals 2000 (1994). H. R. 1804 Goals 2000: Educate America Act. Retrieved from http://www.ed.gov/legislation/GOALS2000/TheAct/intro.html

Hahn, C. L., \& Alviar-Martin, T. (2008). International political socialization research. In L. S. Levstik \& C. A. Tyson (Eds.), Handbook of Research in Social Education(pp. 65-80). Routledge: Woburn Press.

Hahn, C. L. (2001a). Rethinking the social studies. Theory into Practice, 40, 14-22.

Hahn, C. L. (2001b). Student views of democracy: the good and bad news. Social Education, 65, 456-461.

Hahn, C. (1998). Becoming Political: Comparative Perspectives on Citizenship Education. Albany, NY: SUNY Press.

Hepburn, M. A. (1990). Educating for democracy: The years following World War II. The Social Studies. 81, 153-160. 
Hutchens, M.J. \& Eveland, W.P. . (2009). The Long-term impact of high school civics curricula on political knowledge, democratic attitudes and civicbehaviors: a multilevel model of direct and mediated effects through communication. The Center for Information \& Research on Civic Learning \& Engagement Working Paper, 65(1-38).

Federal Reserve Bank of St. Louis. (2011). Unemployment rate in Miami Dade county, $\mathrm{Fl}$ (flmiam6urn). Retrieved from http://research.stlouisfed.org/fred2/series/FLMIAM6URN

Griggs, S. \& Dunn, R.(1996). Hispanic-American students and learning style. ERIC Digest, 1-6.

Ichilov, O. (1998). Conclusion. The challenge of citizenship education in a changing world. In O. Ichilov (Ed.) Citizenship and citizenship education in a changing world. 267-273. London, UK : The Woburn Press.

Kahne, J. (2009). Closing the civic opportunity gap: how schools can promote political equality. Social Studies Review, 48(1), 28-31.

Kahne, J. \& Middaugh, E. (2008). Democracy for some: The civic opportunity gap in high school. The Center for Information \& Research on Civic Learning \& Engagement WORKING PAPER, 59, 1-30.

Kenney, L.C. (2003). Back from the block-or not? Some schools abandon their block scheduling, though others swear by its impact.. School Administrator, 60(9), 21-25.

Lave, J. and Wenger, E. (1991). Situated learning: Legitimate peripheral participation. Cambridge : Cambridge University Press.

Leming, J.S. (2001). Historical and ideological perspectives on teaching moral and civic virtue. International Journal of Social Education. 16, 62-76.

Levine, P. Lopez, M. , \& Marcelo, K.B. (2006) . Getting narrower at the base: The American curriculum after NCLB. The Center for Information \& Research on Civic Learning \& Engagement

Levine, P., \& Lopez, M.H. . (2004). Themes emphasized in social studies and civics classes: new evidence. The Center for Information \& Research on Civic Learning \& Engagement, 1-5.

Levinson, M. (2007). The Civic achievement gap. The Center for Information \& Research on Civic Learning \& Engagement Working Paper, 51 
Levinson , Bradley A. U. (2005).Citizenship, identity, democracy: Engaging the political in the anthropology of education. Anthropology and Education Quarterly. 36, 329-340.

Lopez, M.H., \& Kirby, E.H. . (2007). U.S. civics instruction: content and teaching strategies. CIRCLE The Center for Information \& Research on Civic Learning \& Engagement, 1-9.

Marcelo, K.B., Lopez, M. , \& Kirby, E.H. . (2007). Civic engagement among minority youth. CIRCLE The Center for Information \& Research on Civic Learning \& Engagement, 1-25.

Mazzei, P. (2009, December 8). Miami-Dade kids hit it big on U.S. math test. The Miami Herald, Retrieved from http://www.miamiherald.com/2009/12/08/1372605/miami-dade-kids-hit-it-bigon.html

Miami-Dade County Public Schools (2008). Miami-Dade County Public Schools statistical abstract 2007-2008. Retrieved June 17, 2009, from Miami-Dade County Public Schools statistical abstract web site: http://drs.dadeschools.net/StatisticalAbstract/sa0708.pdf

Miami-Dade County Public Schools (2007). Miami-Dade County Public Schools statistical highlights. Retrieved November 17, 2007, from Miami-Dade County Public Schools statistical highlights web site: http://drs.dadeschools.net/Highlights/Highlights 2006-07.pdf

Mitchell, K., \& Parker, W. C. (2008). I pledge allegiance to . . flexible citizenship and shifting scales of belonging. Teachers College Record, 110(4), 775-804.

Montoya, L.J. (1996). Latino gender differences in public opinion: Results from the Latino national political survey. Hispanic Journal of Behavioral Sciences, 18 , 255-276.

NCSS Task Force on Revitalizing Citizenship Education, (2001). Creating effective citizens. Retrieved July 24, 2007, from National Council for the Social Studies Web site: http://www.socialstudies.org/positions/effectivecitizens/

NCSS Task Force on Character Education in the Social Studies, (1997). Fostering civic virtue: Character education in the social studies. Retrieved February 1, 2010, from National Council for the Social Studies Web site: http://www.socialstudies.org/positions/character

Niemi, R. and Junn, J., (1998). Civic Education: What Makes Students Learn. New Haven, CT: Yale University Press. 
Office of Management and Budget. (2009). Federal register notice

October 30, 1997. Retrieved from

http://www. Whitehouse.gov/omb/fedreg_1997standards/

Paige, R. (2003). Civics education in America. Phi Delta Kappan . 85, 59.

Parker, W.C. (2008). Knowing and doing in democratic citizenship education.

In L.S. Levstik \& C.A. Tyson (Eds.) Handbook of Research in Social Education (pp. 65-80). Routledge: The Woburn Press.

Parker, W.C. (2006). Public discourses in schools: purposes, problems, possibilities. Educational Researcher, 35(8), 11-18.

Parker, W.C. (2005). Teachig against idiocy. Phi Delta Kappan, 86(5), 344-351.

Parker, W. (2001). Educating democratic citizens: a broad view. Theory into Practice, $40(1), 6-13$.

Parker, W.C. (1996). "Advanced" ideas about democracy: toward a pluralist conception of citizen education. Teachers College Record, 98, 104-125.

Passel, J.S., Cohn, D., \& Lopez, M.H. (2011). Census 2010: 50 million Latinos Hispanics account for more than half of nation's growth in past decade. Pew Hispanic Center, 1-8.

Pepper, K., Burroughs , S., \& Groce, E. (2003). Teaching civic in a democratic society: A comparison of civic education in Hungary and the United States. Educational Foundations. 17, 29-5

Perliger, A., Canetti-Nasim, D., \& Pedahzur, A. (2006). Democratic attitudes among high school pupils: The role played by perceptions of class climate. School Effectiveness and School Improvement, 17, 119-140

Reimers, F. (2007). Civic education when democracy is in flux: the impact of empirical research onpolicy and practice in Latin America. . Citizenship and Teacher Education, 3(2), 1-17.

Saenz, V.B. , \& Ponjuan, L. . (2009). The vanishing Latino male in higher education. Journal of Hispanic Higher Education, 8, 54-89.

Sanchez, B., Colon, Y., \& Esparza , P. . (2005). The Role of sense of school belonging and gender in the academic adjustment of Latino adolescents. Journal of Youth and Adolescence, 34(6), 619-628. 
Shernoff, D.J., \& Schmidt, J.A. (2008). Further Evidence of an engagementachievement paradox among U.S. high school students. Journal of Youth Adolescence, 37, 564-580.

Schulz, W. \& Sibberns, H. (Eds.) (2004) Civic Knowledge and Engagement: Technical Report on the IEA Civic Education Study. Amsterdam: IEA.

Sullivan, J.R. , Riccio, C.A. , \& Reynolds, C.R. . (2008). Variations in students' schooland teacher-related attitudes across gender, ethnicity, and age. Journal of Instructional Psychology, 35(3), 296-396.

The Economist (2009). The Latinobarómetro poll: A slow maturing of democracy Retrieved from http://www.economist.com/world/americas/displaystory.cfm?story_id=15080535

The Economist (2008). The Economist intelligence unit's index of democracy 2008.

Torney-Purta, J., Barber, C. H., \& Wilkenfeld, B. (2007). Latino adolescents' civic development in the united states: Research results from the IEA civic education study. Journal of Youth and Adolescence, 36(2), 111-125. Retrieved from http://dx.doi.org/10.1007/s10964-006-9121-y

Torney-Purta, J., Barber, C., \& Wilkenfeld, B. (2006). Differences in the civic knowledge and attitudes of adolescents in the United States by immigrant status and 81emocrac background. Prospects: Quarterly Review of Comparative Education, 36(3), 343-354. Retrieved from http://dx.doi.org/10.1007/s11125-006-0015-2

Torney-Purta, J. (2002). What adolescents know about citizenship and democracy. Educational Leadership, 59(4), 45-50. Retrieved from www.csa.com

Torney-Purta, J. (2000). Comparative perspectives on political socialization and civic education. Comparative Education Review, 44(1), 88-95. Retrieved from www.csa.com

Torney-Purta, J., Lehmann, R., Oswald, H., \& Schulz, W. (2001). Citizenship and education in twenty-eight countries: Civic knowledge and engagement at age fourteen. Amsterdam: IEA.

Torney, J. Oppenheim, A. and Farnen, R. (1975). Civic Education in Ten Countries. New York: John Wiley and Sons.

U.S. Census Bureau, (2010). American fact finder Washington, DC: Retrieved from http://factfinder.census.gov/home/en/epss/glossary a.html 
U.S. Census Bureau. (2009). Hispanic population of the United States.

Retrieved from

http://www.census.gov/population/www/socdemo/hispanic/hispdef.html

U.S. Department of Education, (2009). Mathematics 2009. The Nation's Report Card. Retrieved from http://nationsreportcard.gov/math 2009/

U.S. Department of Education, (2007). Civics 2006. The Nation's Report Card . 1-36.

Valencia, E.Y. , \& Johnson, V. . (2006). School environment, and academic aspirations Latino students in North Carolina: acculturation, perceptions of. Behavioral Sciences Hispanic Journal of, 28, 350-367.

Verba, Sidney and Nie, Norman H. 1972. Participation in America. New York: Harper and Row.

Weinfurt, K. P. (1995). Multivariate analysis of variance. In L. G. Grimm \& P. R. Yarnold (Eds.), Reading and understanding multivariate statistics, pp. 245-276. Washington DC: American Psychological Association

Wenger, E. (1998). Communities of practice: Learning, meaning, and identity. Cambridge : Cambridge University Press.

Westheimer, J., \& Kahne, J. . (2003). Reconnecting education to 82emocracy: democratic dialogues. Phi Delta Kappan, 85(1), 8-14.

White, W.E., Scotter, R.V., Hartoonian, H.M., \& Davis, J.E. (2007). The problem: Democracy at risk. The Social Studies, 98(6), 228-230.

Wilkenfeld, B. (2009). Does Context matter? How the family, peer, school, and neighborhood contexts relate to adolescents' civic engagement. CIRCLE Working Paper, 64, 1-14.

Wrinkle, R.D., Stewart, J. , Polinard, J.L. , Meier, K. , \& Arvizu, J.R. . (1996). Ethnicity and nonelectoral political participation. Hispanic Journal of Behavioral Sciences, $18,142-153$.

Yates, M., \& Youniss, J. (1998). Community service and political identity development in adolescence. Journal of Social Issues, 54(3), 495-512.

Zill, N. (2002).The Public Perspective: A Roper Center review of public opinion and polling. Public Perspective (online). 13, 27-30. 
This test booklet is in three parts. Use the first session (period) to complete Part One and Two.

Stop when you see the STOP sign.

At the end of the first session you will be given a short break. Do NOT start Part

Three until after the break.

\section{Part One}

\section{DIRECTIONS FOR PART 1}

You will have 25 minutes to answer the 16 questions in this section. Each of the questions or incomplete statements in this test is followed by four possible answers. You are to decide which one of these answers is best.

Mark your answer by placing a cross $(\mathrm{X})$ in the box next to the answer you think is correct.

\section{E1. Which of the following is a nation?}
A. $\square$ Tokyo
B. $\square$ Australia
C. $\square$ Copenhagen
D. $\square$ Montreal

Since Australia is a nation and the others are only cities, you should have chosen the answer B as shown below. 
E1. Which of the following is a nation?
A. $\square$ Tokyo
B. $\boldsymbol{x}$ Australia
C. $\square$ Copenhagen
D. $\square$ Montreal

Check only one answer for each question. If you want to change an answer, be sure to erase the old answer completely.

Read each question carefully and answer it as well as you can. Do NOT spend too much time on any one question. If you are not sure about the answer to a question, choose the answer you think is best and continue with the next question on the test.

You are now ready to begin the test.

1. Which of the following is an accurate statement about laws?
A. $\square$ Laws forbid or require certain actions [behaviors].
B. $\square$ Laws are made by the police.
C. $\square$ Laws are valid only if all citizens have voted to accept them.
D. $\square$ Laws prevent criticism of the government.

2. Which of the following is a political right? The right ...
A. $\square$ of pupils to learn about politics in school
B. $\square$ of citizens to vote and stand for [run for] election
C. $\square$ of adults to have a job
D. $\square$ of politicians to have a salary 
3. A woman who has a young child is interviewed for a job at a travel agency. Which of the following is an example of discrimination [injustice]? She does not get the job because...
A. $\square$ she has no previous experience.
B. $\square$ she is a mother.
C. $\square$ she speaks only one language.
D. $\square$ she demands a high salary.

4. In a democratic country [society] having many organizations for people to join is important because this provides...
A. $\square$ a group to defend members who are arrested.
B. $\square$ many sources of taxes for the government.
C. $\square$ opportunities to express different points of view.
D. $\square$ a way for the government to tell people about new laws. 


\section{In democratic countries what is the function of having more than one political party?}
A. $\square$ To represent different opinions [interests] in the national legislature [e.g., Congress]
B. $\square$ To limit political corruption
C. $\square$ To prevent political demonstrations
D. $\square$ To encourage economic competition

6. In a democratic political system, which of the following ought to govern the country?
A. $\square$ Moral or religious leaders
B. $\square$ A small group of well-educated people
C. $\square$ Popularly elected representatives
D. $\square$ Experts on government and political affairs

7. What is the major purpose of the United Nations?
A. $\square$ Safeguarding trade between countries
B. $\square$ Maintaining peace and security among countries
C. $\square$ Deciding where countries' boundaries should be
D. $\square$ Keeping criminals from escaping to other countries 


\section{Which of the following is most likely to cause a government to be called non-democratic?}
A. $\square$ People are prevented from criticizing [not allowed to criticize] the government.
B. $\square$ The political parties criticize each other often.
C. $\square$ People must pay very high taxes.
D. $\square$ Every citizen has the right to a job.

9. Which of the following is most likely to happen if a large publisher buys many of the [smaller] newspapers in a country?
A. $\square$ Government censorship of the news is more likely.
B. $\square$ There will be less diversity of opinions presented.
C. $\square$ The price of the country's newspapers will be lowered.
D. $\square$ The amount of advertising in the newspapers will be reduced.

10. Two people work at the same job but one is paid less than the other. The principle of equality would be violated if the person is paid less because of ...
A. $\square$ fewer educational qualifications.
B. $\square$ less work experience.
C. $\square$ working for fewer hours.
D. $\square$ gender [sex]. 
The next three questions are based on the following imaginary political leaflet [political advertisement].

\section{We citizens have had enough!}

A vote for the Silver Party means a vote for higher taxes.

It means an end to economic growth and a waste of our nation's resources.

Vote instead for economic growth and free enterprise.

Vote for more money left in everyone's wallet!

Let's not waste another 4 years! VOTE FOR THE GOLD PARTY.

11. This is an election leaflet [political advertisement] which has probably been issued by...
A. $\square$ the Silver Party.
B. $\square$ a party or group in opposition to [running against] the Silver Party.
C. $\square$ a group which tries to be sure elections are fair.
D. $\square$ the Silver Party and the Gold Party together.

12. The authors of the leaflet think that higher taxes are...
A. $\square$ a good thing.
B. $\square$ necessary in a [free] market economy.
C. $\square$ necessary for economic growth.
D. $\square$ a bad thing. 


\section{The party or group that has issued this leaflet is likely} also to be in favor of...
A. $\square$ reducing state [government] control of the economy.
B. $\square$ lowering of the voting age.
C. $\square$ capital punishment.
D. $\square$ more frequent elections.

The next two questions differ from those earlier in the test. The following question contains three statements of fact and one statement of opinion. Read each question, and then choose the opinion.

\section{Three of these statements are facts and one is an opinion. Which of the following is an OPINION?}
A. $\square$ Actions by individual countries are the best way to solve environmental problems.
B. $\square$ Many countries contribute to the pollution of the environment.
C. $\square$ Some countries offer to co-operate in order to diminish acid rain.
D. $\square$ Water pollution often comes from several different sources.

\section{Three of these statements are opinions and one is a fact. Which of the following is a FACT [the factual statement]?}
A. $\square$ People with very low incomes should not pay any taxes.
B. $\square$ In many countries rich people pay higher taxes than poor people.
C. $\square$ It is fair that some citizens pay higher taxes than others.
D. $\square$ Donations to charity are the best way to reduce differences between rich and poor.




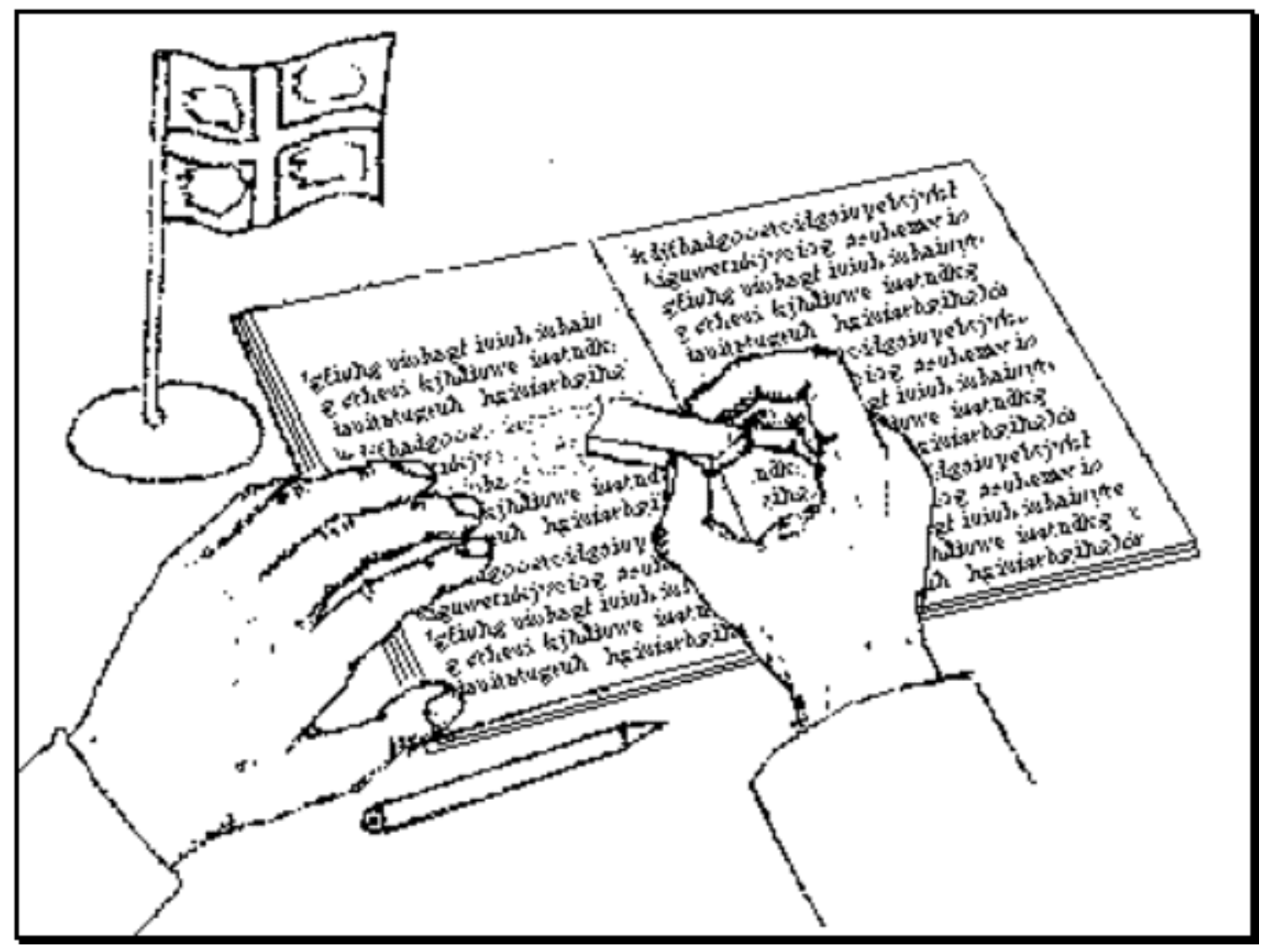

\section{What is the message or main point of this cartoon? History textbooks...}

A. are sometimes changed to avoid mentioning problematic events from the past.

B. for children must be shorter than books written for adults.

C. are full of information that is not interesting.

D. should be written using a computer and not a pencil. 


\section{Part Two}

\section{General Instructions:}

The questions which follow are being asked to students of your age in other middle schools in Miami-Dade County Public Schools. Answers to these questions help in interpreting the answers you give in other parts of this booklet.

Your answers will be CONFIDENTIAL. Your teachers will not see them. Other students will not see them. Please be careful in reading the instructions and answer the questions honestly.

\section{On what date were you born?}

Write in the month, day and year.

month day ___ year

2. Are you a girl or a boy?

Check one box only.

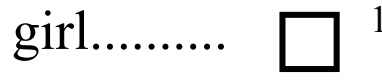

boy........... $\square^{2}$

\section{Which best describes you? \\ Check one box only.}

[A]...White (non-Hispanic)....

[B]....Black (non-

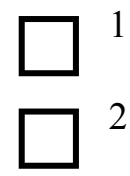

Hispanic)...................... 
[C]....Hispanic................... $\quad \square{ }^{3}$

[D]...American Indian....................... $\quad \square^{4}$

[E]....Asian Indian............................. $\quad \square^{5}$

[F]...Chinese $\quad \square^{6}$

[G]....Filipino...................... $\quad \square^{7}$

$[\mathrm{H}]$....Japanese.................. $\quad \square^{8}$

[I]...Korean..................... $\quad \square^{9}$

$[\mathrm{J}]$....Vietnamese.......................... $\quad \square^{10}$

$[\mathrm{K}]$...Native Hawaiian.... $\quad \square^{11}$

[L].... Other Asian - Print race, for $\quad \square{ }^{12}$ example, Hmong, Laotian, Thai, Pakistani, Cambodian, and so on.

$[\mathrm{M}] \ldots . .$. Some other race - Print 13

Race.

If you marked Hispanic, what nationality are you or your parents?

[A] ...Argentina..................................... $\square \square^{1}$

..

[B]....Bolivia....................................... $\square^{2}$

..

[C]....Chile....................................... $\square \square^{3}$

[D]...Colombia.................................... $\square^{4}$

..

[E].... Costa

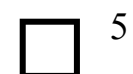

Rica...................................

$[\mathrm{F}] \ldots \mathrm{Cuba}$

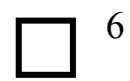

[G]....Dominican

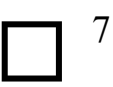

Republic. 
$[\mathrm{H}] \ldots$. Ecuador................................... $\square^{8}$

$[\mathrm{I}] \ldots \mathrm{El} \quad \square^{9}$

Salvador.

$[\mathrm{J}]$....Guatemala................................... $\quad \square^{10}$

$[\mathrm{K}] \ldots$ Honduras........................ $\square \square^{11}$

[L]....Mexico. $\quad \square{ }^{12}$

$[\mathrm{M}]$....Nicaragua................................. $\square \square^{13}$

$[\mathrm{N}]$...Panama..................................... $\square^{14}$

$[\mathrm{O}]$...Paraguay...................................... $\quad \square^{15}$

$[\mathrm{P}] \ldots .$. Peru............................................. $\square^{16}$

$[\mathrm{Q}]$...Uruguay....................................... $\square \square^{17}$

[R]....Venezuela. $\quad \square^{18}$

[S]....Puerto $\quad \square^{19}$

Rico.......................

$[\mathrm{T}]$....Don't Know .................... $\square{ }^{20}$

4. Were you born in the United States?

No.......... $\square^{1}$

Yes......... $\square^{2}$

5. If you were not born in the United States, how old were you when you came to the United States?

Write in your age at the time.

I was ___ years old when I came to the United States. 
6. How often do you speak English at home?

Check one box only.

Never.

Sometimes.

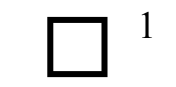

Always or almost always......

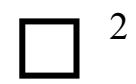

7. Are you currently enrolled in an ESOL Language Arts class?

Check one box only.

Yes......................................

No.................................... $\square^{2}$

8. If you answered NO in question 7, have you ever been enrolled in an ESOL Language Arts class?

Check one box only.

Yes.

No.

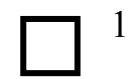

$\square 2$

9. Does any of these people live at home with you most or all of the time?

\begin{tabular}{|c|c|}
\hline no & yes \\
\hline 1 & 2 \\
\hline
\end{tabular}

Mother or stepmother or female guardian...........

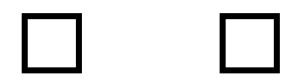

Father or stepfather or male guardian................

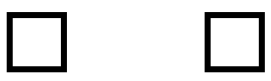


10. Altogether, how many people live in your home?

Write in the total number of people. (Don't forget to include yourself.)

In the next few questions think about the days on which you attend school.

11. How often do you spend time [directly] after school talking [hanging out] with your friends?

Almost every day (4 or more days a

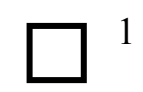
week).......

Several days ( 1 to 3 days a week)....................

A few times each

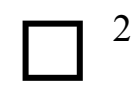

month....................................

Never or almost

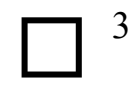

never.....................................

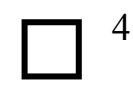

12. How often do you spend time during the evening [after dinner] outside your home with your friends?

Almost every day (4 or more days a

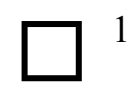
week).......

Several days ( 1 to 3 days a week)....................

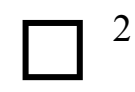

A few times each

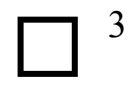

month...................................

Never or almost

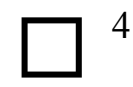

never................................ 
13. How much time do you spend watching television or playing video games on school days?

no time

less than 1 hour.

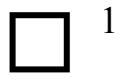

1-2 hours

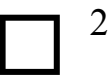

3-5 hours

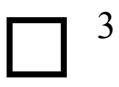

3-5 hours....

more than 5 hours

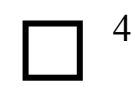

14. How much time do you spend on the Internet on non-school related activities on school days?

no time

less than 1 hour.

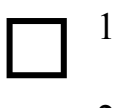

$1-2$ hours

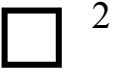

3-5 hours

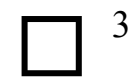

5-7hours.

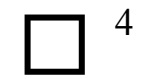

$5-7$ hours....

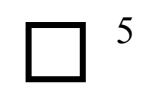

more than 7 hours

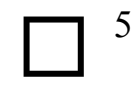

15. Do you receive free or reduced lunch?

No......................... $\square{ }^{1}$

Yes..................... $\square{ }^{2}$

16. Did you complete a $7^{\text {th }}$ grade Civics course in MiamiDade County Public Schools last year? (If you attended a charter school or private school in Miami-Dade County last school year, please mark No.)

No

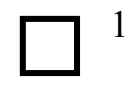

Yes..................... $\square^{2}$ 
When you have finished Part 2, do not proceed any further until after the break.

\section{Part Three}

\section{General Instructions:}

The questions in this part are being asked to students of your age all over MiamiDade County Public Schools.

For the questions which follow there are NO RIGHT OR WRONG ANSWERS.

Your answers will be CONFIDENTIAL. Your teachers will not see them. Other students will not see them.

Please be careful in reading the instructions for the different sets of questions, and be as honest as you can in saying what you think. 


\section{Section C: Trust in Institutions}

In this section we will name several institutions in the United States of America.

\section{How much of the time can you trust each of the following institutions?}

Consider each of these institutions and select the box in the column which shows how you feel you can trust them.

\begin{tabular}{|c|c|c|c|c|c|}
\hline & never & $\begin{array}{l}\text { only some } \\
\text { of the time }\end{array}$ & $\begin{array}{l}\text { most of the } \\
\text { time }\end{array}$ & always & don't know \\
\hline & 1 & 2 & 3 & 4 & 0 \\
\hline $\begin{array}{l}\text { C1... The national [federal] } \\
\text { government [in Washington, } \\
\text { D.C. (the national seat of } \\
\text { government)]. }\end{array}$ & & & & & \\
\hline 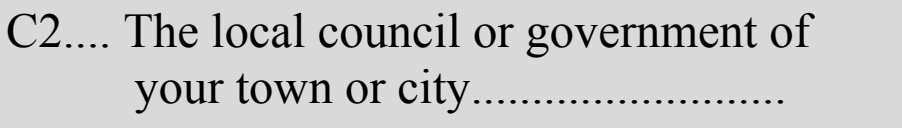 & & & & & \\
\hline 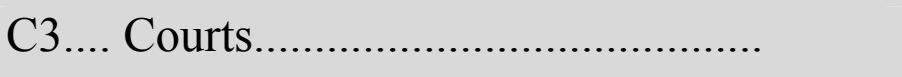 & & & & & \\
\hline 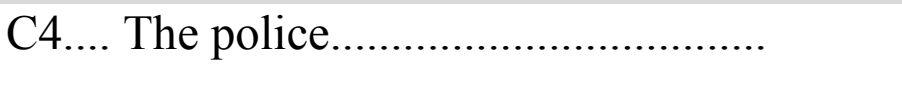 & & & & & \\
\hline C5.... Political parties................................... & & & & & \\
\hline C6.. Congress (Senate and House of Representatives & & & & & \\
\hline
\end{tabular}




\section{Section E: Opportunities}

In this section there are some statements about the opportunities which members of certain groups SHOULD HAVE in the United States of America.

Please read each statement and select the box in the column which corresponds to the way you feel about the statement.

\begin{tabular}{|c|c|c|c|c|c|}
\hline & $\begin{array}{l}\text { strongly } \\
\text { disagree }\end{array}$ & disagree & agree & $\begin{array}{c}\text { strongly } \\
\text { agree }\end{array}$ & $\begin{array}{l}\text { don't } \\
\text { know }\end{array}$ \\
\hline & 1 & 2 & 3 & 4 & 0 \\
\hline 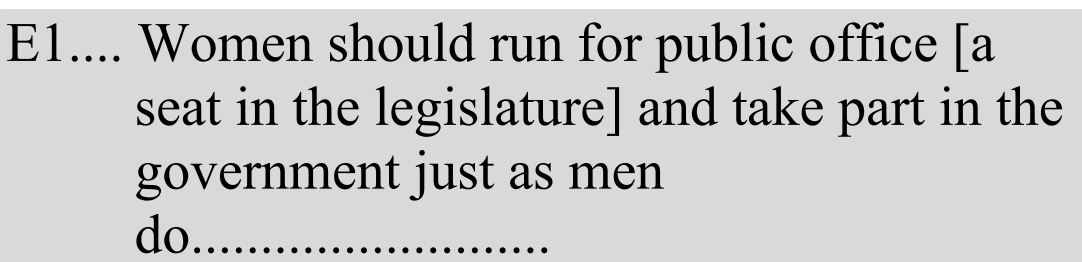 & $\square$ & $\square$ & $\square$ & $\square$ & 0 \\
\hline $\begin{array}{l}\text { E2... Women should have the same rights as } \\
\text { men in every }\end{array}$ & $\square$ & $\square$ & $\square$ & $\square$ & 0 \\
\hline 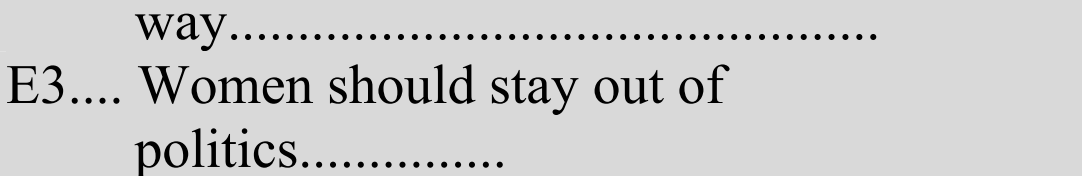 & $\square$ & $\square$ & $\square$ & $\square$ & 0 \\
\hline
\end{tabular}


Opportunities 2 (continued) -

\begin{tabular}{|c|c|c|c|c|c|}
\hline & $\begin{array}{l}\text { strongly } \\
\text { disagree }\end{array}$ & disagree & agree & $\begin{array}{c}\text { strongly } \\
\text { agree }\end{array}$ & $\begin{array}{l}\text { don't } \\
\text { know }\end{array}$ \\
\hline & 1 & 2 & 3 & 4 & 0 \\
\hline $\begin{array}{l}\text { E4... When jobs are scarce, men [should] have } \\
\text { more right to a job than } \\
\text { women.................. }\end{array}$ & $\square$ & $\square$ & $\square$ & $\square$ & 0 \\
\hline $\begin{array}{l}\text { E5.. Men and women should get equal pay } \\
\text { when they are in the same jobs } \\
\text { [occupations]....... }\end{array}$ & $\square$ & $\square$ & $\square$ & $\square$ & 0 \\
\hline $\begin{array}{l}\text { E6.. Men are better qualified to be political } \\
\text { leaders than women................................ }\end{array}$ & $\square$ & $\square$ & $\square$ & $\square$ & 0 \\
\hline
\end{tabular}




\section{Section F: Immigrants}

Listed below you will read several statements about immigrants and immigration in United States of America.

Please read each statement and select the box in the column which corresponds to the way you feel about the statement.

\begin{tabular}{|c|c|c|c|c|}
\hline $\begin{array}{l}\text { strongly } \\
\text { disagree }\end{array}$ & disagree & agree & $\begin{array}{c}\text { strongly } \\
\text { agree }\end{array}$ & $\begin{array}{l}\text { don't } \\
\text { know }\end{array}$ \\
\hline 1 & 2 & 3 & 4 & 0 \\
\hline
\end{tabular}

F1.. Immigrants should have the opportunity [option] to keep [continue speaking] their own language

F2.. Immigrants' children should have the same opportunities for education that other children in the country have.

F3.. Immigrants who live in a country for several years should have the opportunity to vote in elections

F4.. Immigrants should have the opportunity [option] to keep [continue] their own customs and lifestyle.

F5.. Immigrants should have all the same rights that everyone else in a country has. 


\section{Section G: School}

Listed below you will find some statements on students' participation in school life.

Please read each statement and select the box in the column which corresponds to the way you feel about the statement.

\begin{tabular}{|c|c|c|c|c|}
\hline $\begin{array}{c}\text { Strongly } \\
\text { disagree }\end{array}$ & disagree & agree & $\begin{array}{c}\text { strongly } \\
\text { agree }\end{array}$ & $\begin{array}{c}\text { don't } \\
\text { know }\end{array}$ \\
\hline
\end{tabular}

G1... Electing student representatives to suggest changes in how the school is run [how to solve school problems] makes schools better.

G2... Lots of positive changes happen in this school when students work together

G3... Organizing groups of students to state their opinions could help solve problems in this school.

G4... Students acting together [in groups] can have more influence on what happens in this school than students acting alone [by themselves] 


\section{Section H: Political Action}

Listed below are several types of action that adults could take: When you are an adult, what do you expect that you will do?

Check one box in each column for each action to show how likely you would be to do it.

\begin{tabular}{|c|c|c|c|c|}
\hline $\begin{array}{c}\text { I will } \\
\text { certainly } \\
\text { not do } \\
\text { this }\end{array}$ & $\begin{array}{c}\text { I will } \\
\text { probably } \\
\text { not do } \\
\text { this }\end{array}$ & $\begin{array}{c}\text { I will } \\
\text { probably } \\
\text { do this }\end{array}$ & $\begin{array}{c}\text { I will } \\
\text { certainly } \\
\text { do this }\end{array}$ & $\begin{array}{c}\text { don't } \\
\text { know }\end{array}$ \\
\hline 1 & 2 & 3 & 4 & 0 \\
\hline
\end{tabular}

H1... Join a political party.

H2... Write letters to a newspaper about social

$\square$ or political concerns

$\mathrm{H} 3 \ldots$ Be a candidate for a local or city office 


\section{Section I: Classrooms}

The next part of the questionnaire includes some statements about things that happen in your school. When answering these questions, think especially about classes in history, civic education or social studies [other civic-related subjects].

Please read each statement and select the box in the column which corresponds to the way you feel about the statement.

\begin{tabular}{|c|c|c|c|c|}
\hline never & rarely & sometimes & often & $\begin{array}{c}\text { don't } \\
\text { know }\end{array}$ \\
\hline 1 & 2 & 3 & 4 & 0
\end{tabular}

I1.... Students feel free to disagree openly with their teachers about political and social issues during class

I2.... Students are encouraged to make up their own minds about issues.

I3... Teachers respect our opinions and encourage us to express them during class. 


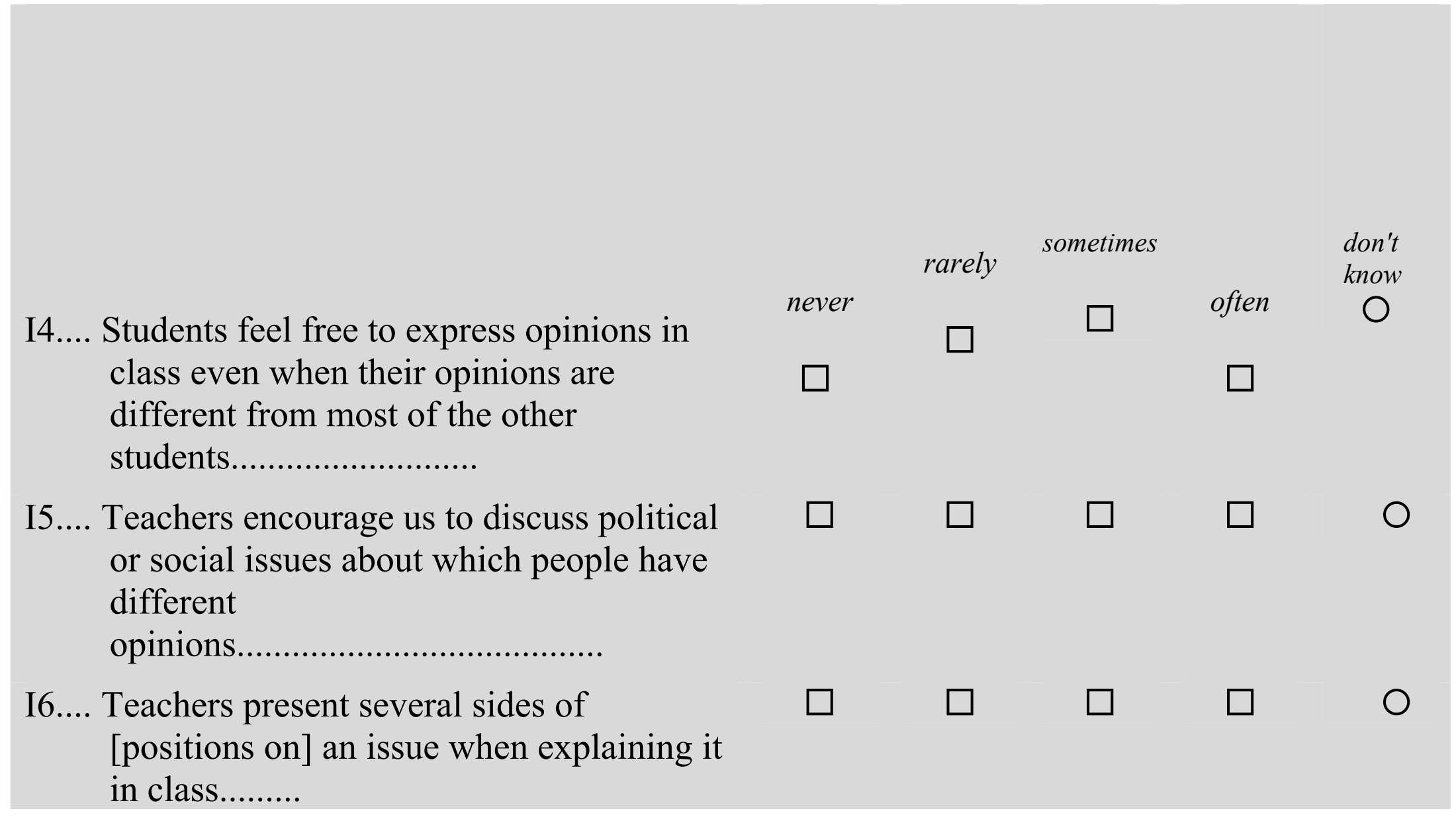


You have now reached the end of the questions. If you have some time left go back to Parts Two and Three and check your answers and make sure you have answered all the questions you feel you can answer.

Many thanks for taking the time to complete this booklet. Your answers will help in understanding and improving the provision of civic education around the world. 
VITA

\section{SERGIO NIEVES}

Born, Miami, Florida

2003

B.A. History

Minor: Political Science

Florida International University

Miami, Florida

2005

M.S. Social Studies Education

Florida International University

Miami, Florida

2009

National Board Certified Teacher:

Early Adolescence/Social Studies-History

National Board for Professional Teaching Standards

Arlington, Virginia

Professional Experience

2008-Present

Social Studies Department Chairperson

Young Women's Preparatory Academy

Miami-Dade County Public Schools

Miami, Florida

2003-2008

Social Studies Teacher

Jose de Diego Middle School

Miami-Dade County Public Schools

Miami, Florida

Professional Presentations

Farouk, M.K. and Nieves, S. (2011, May) The Civic Achievement Gap: A Study of the Civic Knowledge, Skills, and Attitudes of Hispanic Students in Miami-Dade County Public Schools. Paper presented at the Comparative International Education Society Annual Conference, Montreal, Québec, Canada.

Farouk, M.K. and Nieves, S. (2010, November) The Civic Achievement Gap: A Study of the Civic Knowledge, Skills, and Attitudes of Hispanic Students in Miami-Dade County Public Schools. Paper presented at the International Assembly of Social Educators, Annual Conference of the National Council for the Social Studies, Denver, CO 